Sergei Bogatyrev (University College London)

s.bogatyrev@ucl.ac.uk

\title{
The Patronage of Early Printing in Moscow
}

The paper re-examines the view that printing and the distribution of printed books in Muscovy was a state monopoly. Like in many other pre-modern societies, the crown and the church were major patrons of the print. And, like in other patronage systems, there was no single approach to the press in Moscow. Ivan IV was interested in printing as a tool for enhancing prestige and securing salvation. The approaches of Orthodox hierarchs ranged from Metropolitan Makarii's pragmatic aims to supply churches with liturgical books to reflective editing and the compilation of discursive colophons under Metropolitan Afanasii. Due to the declining quality of their printed output, Ivan Fedorov and Petr Mstislavets lost Afanasii's patronage. The centralized pattern of patronage precluded them from finding alternative sources of printing jobs in Muscovy. It was not political persecutions or cultural prejudices against printing, but the centralization of printing in Muscovy that caused the printers to leave for Poland-Lithuania. In attempts to secure orders and find new patrons at the new location, Ivan Fedorov sought to utilize the model of patronage that he learned to operate in Moscow.

Key words: Muscovy, Orthodox church, early printing, Ivan Fedorov, book culture, patronage, Ivan IV the Terrible, Metropolitan Makarii, Metropolitan Afanasii.

Historians of early printing often emphasize differences between printing in the West and other parts of the world. Patronage is one of them. According to Elisabeth Eisenstein, printing had a transforming power in the West, where printers were the natural enemies of regimes that imposed licensing and censorship. Eisenstein admits that her study is limited to Western Christianity. In other societies, in her view, the monopolization of the print by rulers and priests could put it into entirely different use. ${ }^{1}$ Robert Mathiesen also lists the centralization of printing in Moscow among the peculiarities of Cyrillic book printing. ${ }^{2}$

The problem of centralization, however, has various aspects. The first is the degree of centralization. For a long time historians assumed that the Muscovite state monopolized the

\footnotetext{
I am grateful to V.I. Ul'ianovs'kyi and Charles Halperin for their comments on this paper. All interpretations and errors remain mine.

${ }^{1}$ Elizabeth L. Eisenstein, The Printing Press as an Agent of Change: Communication and Cultural Transformations in Early-Modern Europe (Cambridge: Cambridge University Press, 2009), 703 (first published in 1979); Elizabeth L. Eisenstein, "An Unacknowledged Revolution Revisited," The American Historical Review (hereafter $A H R$ ), 107 (2002), 1: 98; Elizabeth L. Eisenstein, “Reply," AHR, 107 (2002), 1: 126.

${ }^{2}$ Robert Mathiesen, "Cyrillic and Glagolitic Printing and the Eisenstein Thesis," Solanus, 6 (1992): 16.
} 
distribution of early printed editions. However, it is clear now that despite the centralized patronage of printing, the Apostol (Acts and Epistles), which Ivan Fedorov and Petr Mstislavets printed in Moscow in 1564, was exposed to the book market almost immediately after its publication. ${ }^{3}$ This combination of centralized and market mechanisms in book printing leads us to the question of whether centralization suggests a common approach to printing between its Muscovite patrons, the crown and the church. Scholars have already demonstrated that Ivan Fedorov had very complex relations with his patrons in Poland-Lithuania, including the Ruthenian magnates Hryhorii Khodkevych and Vasyl'Kostiantyn Ostroz'kyi (of Ostroh) and members of the L'viv Orthodox community. ${ }^{4}$ At the same time, research into the patronage of printing in Moscow is too often marred by nationalistic views of the history of printing. Such views are based on a contentious claim that the Russian state and the Russian church were the only guardians of Orthodoxy in the world and had a common aim to spread it through printing. This is why the state provided funds to printers working in Moscow. ${ }^{5}$

Printers, including Ivan Fedorov, indeed constantly needed cash because the narrow market of early printed books generated small income, if any. Modern studies, however, show that the relations between the patron and the printer were not limited to finances. Despite their superior position, patrons also benefitted from contacts with printers by gaining prestige and fame. Patronage thus involved not only subordination, but also partnership. ${ }^{6}$ To what extent are these modern views of patronage applicable to Muscovite centralized

\footnotetext{
${ }^{3}$ See E.L. Nemirovskii, Ivan Fedorov i ego epokha: Entsiklopediia (Moscow: Entsiklopediia, 2007), 99-100.

${ }^{4}$ See lu.A. Labyntsev, L.L. Shchavinskaia, Pravoslavnaia Akademiia Khodkevichei i ee izdaniia (Minsk: Institut slavianovedeniia i balkanistiki RAN, Natsional'naia biblioteka Belarusi, 1996); Michelle Ruth Viise, Culture of the Christian Orthodox Printing House in Sixteenth-and Seventeenth-century Poland-Lithuania, PhD dissertation (Berkeley, CA: University of California, 2006) and V.I. Ul'ianovs'kyi's paper in this volume.

${ }^{5}$ A.V. Voznesenskii, K istorii slavianskoi pechatnoi Psaltiri. Moskovskaia traditsiia XVI-XVII vekov: Prostaia psaltir' (Moscow, St. Petersburg: Al'ians-Arkheo, 2010), 65.

${ }^{6}$ On the patronage of early printing in different cultures, see Peter J. Lucas, "The Growth and Development of English Literary Patronage in the Later Middle Ages and Early Renaissance," The Library, Sixth Series, 4 (1982), 3: 219-248; Lotte Hellinga, "Printing," in Lotte Hellinga, J.B. Trapp, eds., The Cambridge History of the Book in Britain, 3: 1400-1557 (Cambridge: Cambridge University Press, 1999), 65-108; Pamela Neville-Sington, "Press, Politics and Religion," in Hellinga, Trapp, The Cambridge History of the Book, 3: 576-607; Graham Parry, "Patronage and the Printing of Learned Works for the Author," in John Barnard and others, eds., The Cambridge History of the Book in Britain, 4: 1557-1695 (Cambridge: Cambridge University Press, 2002), 174188; Natalia Nowakowska, "High Clergy and Printers: Anti-Reformation Polemic in the Kingdom of Poland, 1520-36," Historical Research, 87 (2014), 235: 43-64; Hildegard Diemberger, "Patronage and Printing Innovation in $15^{\text {th }}$-century Tibet," in Anastasia Piliavsky, ed., Patronage as Politics in South Asia (Cambridge: Cambridge University Press, 2014), 346-364.
} 
institutions? To answer this question, we need to look at the chronology of patronage in Moscow, various forms of this patronage and Ivan Fedorov's recollections of his Muscovite patrons in his later editions published in Poland-Lithuania.

\section{Chronology of Patronage}

Unlike their Ruthenian counterparts, Muscovite patrons left no pragmatic statements explaining their aims. Our knowledge about the patronage of printing in Moscow mainly comes from the introductions and colophons of Ivan Fedorov's editions. These sources contain two kinds of information about the subject, narrative accounts of patronage and chronological records. The earliest and most important narrative about the patronage of early printing in Moscow can be found in the colophon of the 1564 Apostol. However, conflicting dates and perplexing punctuation muddle the colophon's syntax, making some places murky (marked with forward slashes and line breaks in the following quote).

By command of the pious Tsar and Grand Prince of all Rus' Ivan Vasil'evich, and with the blessing of the eminent Metropolitan Makarii, an inquiry into the art of printing books started / in the year $7061(1552 / 53) /$

in the thirtieth year of his reign (1562/63) /

the faithful tsar ordered that a house be furnished by his royal treasury, where the work of printing could be done, and gave unsparingly from his royal wealth to the workers, the deacon Ivan Fedorov of [the church of] Saint Nicholas the Miracle Worker of Gostun, ${ }^{7}$ and Petr Timofeev Mstislavets. ${ }^{8}$

\footnotetext{
${ }^{7}$ This church, which was located in the Kremlin, received its name after the Gostun' miracle working icon of St. Nicholas.

${ }^{8}$ Apostol (Moscow: Ivan Fedorov, Petr Timofeev Mstislavets, 1564), fols. 260-261 (British Library, C.104.k.11, on this copy see Ekaterina Rogatchevskaia's paper and my coda in this collection). For a facsimile reproduction, see M.N. Tikhomirov and others, eds., $U$ istokov russkogo knigopechataniia (Moscow: Izdatel'stvo AN SSSR, 1959), 217-219 plates 1-3. Translation adopted from George Vernadsky and others, eds., A Source Book for Russian History from Early Times to 1917, 1 (New Haven, London: Yale University Press, 1972), 171-172.
} 
This passage poses several questions: did the above-mentioned inquiry into the art of printing and the establishment of a printing press occur in different years? or did they happen in the same year? and if the latter, what year was it? To answer these questions scholars tried to correlate the chronology of the 1564 colophon with Ivan Fedorov's later accounts of the beginning of printing in Moscow. However, his later texts and their chronology are biased (see below). This is why a formal analysis of the chronological records in the 1564 colophon is more promising. E.L. Nemirovskii has established that the printer never used regnal years (years from the beginning of a ruler's or an official's period in office) without indicating years from the Creation (Appendix I). ${ }^{9}$ In addition to this important observation one may note that in Ivan Fedorov's editions dates always follow relevant events and never precede them. Both problematic dates in the colophon therefore refer to the event mentioned just before them, initial inquiry about printing.

The colophon's dates were thus supposed to indicate the same year, but one of them is erroneous. The error is in the regnal year of Ivan IV (should be twentieth instead of thirtieth), as N.M. Karamzin, Archimandrite Leonid (L.A. Kavelin) and M.I. Shchelkunov argued long time ago. ${ }^{10}$ From a technical point of view, it was easy to confuse the Cyrillic numerals $\lambda(30)$ and $\kappa(20)$. Such an error appears in the Lenten Triodion (Triod' postnaia) that was printed in Moscow in ca. $1555 .{ }^{11}$ Ivan Fedorov and Petr Mstislavets also made errors in regnal years, as evidenced by two editions of the Book of Hours, which they finished in Moscow respectively on 29 September 7074 (1565) and 29 October 7074 (1565)..$^{12}$ The colophons of both editions date the completion of work to the thirty first year

\footnotetext{
${ }^{9}$ Nemirovskii, Ivan Fedorov i ego epokha, 109. Nemirovskii's own view is that Ivan Fedorov deliberately confused the dates to avoid direct references to a printing press that worked in Moscow in the 1550s for political reasons, but, as an honest man, could not omit its work completely. This explanation is exaggerated. See la.D. Isaevyich, Literaturna spadshchyna Ivana Fedorova (L'viv: Vyshcha shkola, 1989), 57.

${ }^{10}$ N.M. Karamzin, Istoriia gosudarstva Rossiiskogo (St. Petersburg: Tipografiia N. Grecha, 1821), Primechaniia, 27 note 89; Leonid, arkhimandrit [L.A. Kavelin], Evangelie, napechatannoe v Moskve, 1564-1568 (Pamiatniki drevnei pis'mennosti i iskusstva 37, St. Petersburg: Tipografiia Dobrodeeva, 1883), 14; M.I. Shchelkunov, Iskusstvo knigopechataniia v ego istoricheskom razvitii, s 16 tablitsami illiustratsii (Moscow: Moskovskii institut zhurnalistiki, 1923), 170. Cf. M.N. Tikhomirov, "Nachalo knigopechataniia v Rossii," in Tikhomirov, U istokov russkogo knigopechataniia, 14.

${ }^{11}$ M.N. Tikhomirov pointed out that error in the printed Lenten Triodion, though without connecting it with the 1564 Apostol. Tikhomirov, "Nachalo knigopechataniia v Rossii," 14, 25.

${ }^{12}$ A.S. Zernova believed that the printers erred in the year $7061(1552 / 53)$, but she was not aware of their mistakes in regnal years. A.S. Zernova, Nachalo knigopechataniia v Moskve i na Ukraine (Moscow: Gos. biblioteka SSSR im. V.I. Lenina, 1947), 33.
} 
of Ivan IV's reign (Appendix I, nos. 2, 3). ${ }^{13}$ The beginning of a new year from the Creation in Muscovy was of course on 1 September; however, a new regnal year of Ivan IV started in December because he ascended the throne in December 1533. This means that both September and October 7074 were in fact the thirty second regnal year of Ivan IV. This is corroborated by diplomatic documents of the Ambassadorial Chancellery: it is precisely the thirty second regnal year that we find in Ivan IV's letter to the Polish king that was written almost simultaneously with the publication of the Book of Hours, in November $7074 .{ }^{14}$

Taken together, the patterns of dating mechanisms employed by Ivan Fedorov and the distribution of errors in regnal years across his Moscow editions suggest the following chronology of patronage: in 1552/53, which was the twentieth regnal year of Ivan IV, the tsar launched, with the blessing of Metropolitan Makarii, an inquiry into printing, something which resulted in the foundation of so-called anonymous press. The anonymous press published several liturgical books with indicating neither the name(s) of their printer(s) nor the date and place of publication in the $1550 \mathrm{~s} .{ }^{15}$ Then Ivan IV made a donation towards the establishment of another press in Moscow and became a patron of Ivan Fedorov and Petr Mstislavets.

Apart from the above-mentioned conflicting dates relating to the beginning of printing in Moscow, the colophon of the 1564 Apostol includes two more chronological notes dating the production of the edition to the period from 19 April 1563, the feast day of loann of the Ancient Caves (Paleolavrit, Palevret) through 1 March 1564, the first regnal year of Metropolitan Makarii's successor, Metropolitan Afanasii. These notes may look like dry

\footnotetext{
${ }^{13}$ Chasovnik, 1st edn. (Moscow: Ivan Fedorov, Petr Timofeev Mstislavets, 7 August - 29 September 1565), [fol. 173]; quoted from Orationes linguâ \& caractere Moscoviticæ (Bruxelles: Culture et civilisation, 1967) (facsimile reproduction of the only known copy from the Royal Library of Albert I in Brussels, II 78.976 B [RP] [Stacks Réserve précieuse: Niv. -2]); Chasovnik, 2nd edn. (Moscow: Ivan Fedorov, Petr Timofeev Mstislavets, 2 September-29 October 1565), [fol. 172] (microfilm of Lambeth Palace Library A32.2/P95.1). For a facsimile reproduction, see Tikhomirov, $U$ istokov, 223 plate 5.

${ }^{14}$ Sbornik Imperatorskago Russkago istoricheskago obshchestva (hereafter Sbornik RIO), 71 (St. Petersburg: Tipografiia A.L. Katanskogo i Ko., 1892), 318.

${ }^{15}$ On the anonymous press, see Nemirovskii, Ivan Fedorov i ego epokha, 79. My article on the Ostroh Bible misdates (due to editorial intervention) the work of the anonymous press to the period before the 1550 s. Sergei Bogatyrev, "The Ostroh Bible from the National Library of Finland," The Slavonic and East European Review, 92 (2014), 4: 706. Recent studies into the watermarks of anonymous editions lend support to the theory about their Muscovite origin. See A.S. Usachev, "Pervye russkie pechatnye knigi: Filigranologicheskie nabliudeniia," in Fedorovskie chteniia 2007 (Moscow: Nauka, 2007), 59-60. Cf. Nataliia Bondar's paper in the present volume.
} 
factual records, but their cultural function is more complex. Dating systems, especially regnal years, could also function as statements of authority. Combinations of different dating systems and changes from one system to another often legitimized the current authorities and reflected the loyalties of printers to their patrons, resulting in what is known as "political dating systems." ${ }^{16}$ A.S. Demin, who has provided an excellent literary analysis of Ivan Fedorov's colophons, has already suggested a link between the printer's dating system and patronage. According to Demin, Ivan Fedorov sought to mention in his chronological notes the names of politically influential and reputable figures, first of all power holders and patrons. At the same time, precise chronology was of secondary importance for the printer. ${ }^{17}$

Appendix I demonstrates that in his editions, Ivan Fedorov used as many as six dating systems based on years from the Creation (AM), years since the birth of Christ (AD), royal regnal years (from the beginning of Ivan IV's reign), metropolitan's regnal years, regnal notes (general references to the reign of the current monarch or metropolitan without specifying regnal years), and, on one occasion, a feast day. Many books printed by Ivan Fedorov contain dual or even triple dates combining different dating mechanisms (Appendix I presents such composite dates in the same row).

Ivan Fedorov applied regnal years exclusively to the Muscovite tsar and metropolitan (Appendix I, nos. 1-3, 6). Despite Eisenstein's criticism of the monopolization of the print by rulers and priests, royal and religious figures were typical patrons of early printing across Eurasia, from England to Tibet. Contrary to the Eisenstein thesis, printers in Western capitals like London and Paris supported licensing that guaranteed trust and order and secured investments. The survival of provincial printers in the West also depended on the support of

\footnotetext{
${ }^{16}$ Deborah Mauskopf Deliyannis, "Year-Dates in the Early Middle Ages," in Chris Humpreys, W.M. Ormrod, eds., Time in the Medieval World (Woodbridge: York Medieval Press, 2001), 12-15. On "political dating systems," see also Heinrich Fichtenau, "Politische" Datierungen des frühen Mittelalters," in Herwig Wolfram, ed., Intitulatio II. Lateinische Herrscher- und Fürstentitel im neunten und zehnten Jahrhundert (Wien-Köln: Graz, Böhlau, 1973, Mitteilungen des Instituts für österreichische Geschichtsforschung, Ergänzungsband, 24), 453548; Helmut Reimitz, History, Frankish Identity and the Framing of Western Ethnicity, 550-850 (Cambridge: Cambridge University Press, 2015), 436.

${ }^{17}$ A.S. Demin, "Russkie staropechatnye poslesloviia vtoroi poloviny XVI v.: Otrazhenie nedoveriia chitatelei k pechatnoi knige," in A.S. Demin and others, eds., Tematika i stilistika predislovii i posleslovii (Russkaia staropechatnaia literatura, XVI - pervaia chetvert' XVIII v., Moscow: Nauka, 1981), 62-63 note 54.
} 
ecclesiastical and municipal institutions. ${ }^{18}$ In their editions printers often celebrated supreme authorities under whose auspices they worked to express their loyalty and accountability. ${ }^{19}$ The acknowledgement of the tsar and the metropolitan in printed books, including Ivan Fedorov's editions, was not just a local tradition going back to hand-written manuscripts, as Demin argued. ${ }^{20}$ Rather, Muscovite printers followed here a standard pattern of early printing. Such acknowledgments were not empty formalities, as evidenced by the Psalter published by Andronik Timofeev Nevezha in 1577. Printed at the royal residence of Aleksandrova Sloboda, the edition acknowledges Tsar Ivan IV, but says nothing about Metropolitan Antonii, who headed then the Orthodox church. The metropolitan, who had no residence at Aleksandrova Sloboda, was not involved in the preparation of the 1577 edition. Why this happened is a different question. What is important is that the printer glorified the royal patron and his dynasty, but not the metropolitan. ${ }^{21}$ Printers were thus selective when they gave credit to people in positions of lay or ecclesiastical authority for supporting publishing. References to the tsar and the metropolitan in Ivan Fedorov's and Petr Mstislavets' editions testify to the royal and church patronage of early printing in Moscow.

\section{Royal Patronage}

Ivan IV's patronage of printing is part of the larger problem of his engagement with book culture and literacy. Traditional scholarship has embraced the idea that Ivan was a versatile author who accessed a large library of books in different languages. ${ }^{22}$ Assertions about

\footnotetext{
${ }^{18}$ Adrian Johns, The Nature of the Book (Chicago: The University of Chicago Press, 1998), 38; 112; Adrian Jones, "How to Acknowledge a Revolution," AHR, 107 (2002), 1: 112; Malcolm Walsby, "The Vanishing Press: Printing in Provincial France in the Early Sixteenth Century," in Malcolm Walsby, Graeme Kemp, eds., The Book Triumphant: Print in Transition in the Sixteenth and Seventeenth Centuries (Leiden: Brill, 2011), 97-111. copy from St. George Chapel, Chapter Library, Windsor, B235, microfilm). Judging by A.V. Voznesenskii's updated description of the 1577 Psalter, the foliation in the Windsor copy reflects the actual number of folios in the edition. Voznesenskii, $K$ istorii, 266-268.

${ }^{22}$ For different views, see N.N. Zarubin, Biblioteka Ivana Groznogo. Rekonstruktsiia i bibliograficheskoe opisanie, ed. A.A. Amosov (Leningrad: Nauka, Leningradskoe otdelenie, 1982); Daniel Clarke Waugh, "The
} 
Ivan's Renaissance library are practically impossible to substantiate because they heavily rely on texts whose reliability as historical sources is debated: a German chronicle and the Correspondence between Ivan IV and Prince A.M. Kurbskii. Nevertheless, scholars are still preoccupied with these sources and ignore what in his 1987 paper Daniel Waugh dismissed as "a few Old Church Slavic religious books that Ivan may or may not have kept beside his bed."23

Subsequent studies have revealed the centrality of Orthodox culture to the Muscovite court, including the royal family. The editors of a festschrift in honor of Daniel B. Rowland, who charted a new path in the studies of Muscovite culture, succinctly summarize current views: "we noted a powerful diffusion of elements of high religious culture down the political and social ladder, and we found that this moral system provided a vocabulary and set of standards that the tsar's subjects could and did invoke in their interactions with authorities." ${ }^{24}$ This is why information about Orthodox books kept in Ivan IV's Kremlin palace is more important for understanding his cultural priorities than debates about his lost library and arguably even the overstudied texts about his falling-out with Kurbskii.

Furthermore, contrary to Waugh, not all of the books held in the palace were in Church Slavonic and religious.

Admittedly, our knowledge about books that surrounded Ivan IV is limited, but a historian of sixteenth-century Muscovy can not expect an abundance of sources. The most important among them is an inventory of items missing from the royal palace after Ivan IV's death, including fourteen books. This list of books is incomplete, because its compilers had no access to previous inventories that were at the sovereign's quarters (u gosudaria). A quick look at the historiography of this crucial source reveals how seriously students of Ivan IV's engagement with book culture misplaced their efforts: the only edition of the document

Unsolved Problem of Tsar Ivan IV's Library," Russian History, 14 (1987), 1-4: 395-408; V.V. Kalugin, Andrei Kurbskii i Ivan Groznyi: Teoreticheskie vzgliady i literaturnaia tekhnika drevnerusskogo pisatelia (Moscow: lazyki russkoi kul'tury, 1998).

${ }^{23}$ Waugh, "Unsolved Problem," 395.

${ }^{24}$ Valerie Kivelson, Karen Petrone, Nancy Shields Kollmann, Michael S. Flier, "The Use and Abuse of Dominant Paradigms in Muscovite Cultural Studies," in Valerie Kivelson and others, eds., The New Muscovite Cultural History. A Collection in Honor of Daniel B. Rowland (Bloomington, IN: Slavica, 2009), 12. 
dates back to 1850 , and the only specialized work about it is a short marginalia, despite S.O. Schmidt's call for a critical reexamination of the inventory as early as $1984 .^{25}$

According to the inventory, books were distributed among several locations in the palace. Most of them were gathered in the sovereign's bedchamber treasury (gosudareva postel'naia kazna): a Sticherarion (Stikharal'); a chronicle from a monastery of the Holy Trinity (apparently, the Trinity-St. Sergii monastery); an illustrated Western herbal, most likely German (kniga nemetskaia na bumage, znamen'e travnik), which was bound together with another unnamed book; a full Gospel (Evangelie tetr) and five Gospels of unspecified types. Some books were also kept in other chambers (komnaty): a herbal, a Euchologion (Potrebnik), a Lenten Triodion (Postnaia Triod') and a Floral Triodion (Tsvetnaia Triod').

To avoid unnecessary associations with the myth of Ivan IV's Renaissance library, it is safer to describe the above-mentioned books in toto as the Palace collection. Furthermore, it would be anachronistic to imagine anything similar to a modern library in Ivan IV's chambers. The books were almost certainly kept in trunks or boxes, as were some Latin books in the royal archive (tsarskii arkhiv). ${ }^{26}$ Books from the Palace collection were registered in inventories, which the royal secretaries periodically updated by marking the provenance and movement of individual copies. Judging by such notes, the Palace collection was part of a book exchange network which included the metropolitan's see, the chancellery staff, Western court physicians, members of the court elite, the clergy of the Kremlin cathedrals and monks from the above mentioned Trinity monastery.

This network interacted with printed culture in several ways. First, the Euchologion that was kept in the Palace collection earlier belonged to Metropolitan Afanasii. The book itself was apparently hand-written, but Afanasii was a patron of Ivan Fedorov and other printers (see

\footnotetext{
25 “Opis' domashnemu imushchestvu tsaria Ivana Vasil'evicha, po spiskam i knigam 90 i 91 godov," in Vremennik Imperatorskogo Moskovskogo obshchestva istorii i drevnostei rossiiskikh, 7 (Moscow: Universitetskaia tipografiia, 1850), Smes', 6-7. G.V. Zharinov, “O proiskhozhdenii tak nazyvaemoi 'Opisi domashnemu imushchestvu tsaria Ivana Vasil'evicha . . .," Arkhiv russkoi istorii, 2 (1992): 179-85. S.O. Shmidt, Rossiiskoe gosudarstvo v seredine XVI stoletiia: Tsarskii arkhiv i litsevye letopisi vremeni Ivana Groznogo (Moscow: Nauka, 1984), 131 note $11^{*}$.

${ }^{26}$ A.A. Zimin, comp., Gosudarstvennyi arkhiv Rossii XVI stoletiia: Opyt rekonstruktsii (Moscow: Institut istorii SSSR AN SSSR, 1978), 65, 294-296.
} 
below). Despire Ivan Fedorov's departure from Moscow and Afanasii's resignation from the metropolitan's see, Ivan IV did not mind the presence of the metropolitan's book in the Palace collection, a sign that Afanasii's posthumous reputation as a bookman was still very high.

Second, the above-mentioned herbals were undoubtedly products of engagement with Western printed culture. Intended for Western physicians at the tsar's service, the illustrated German medical book from the Palace collection was obviously printed. ${ }^{27}$ The second herbal on the list of the Palace collection could have been a Slavonic translation of a Western printed edition. Such translations exemplify what Simon Franklin calls "reverse technological transfer" when Western printed material generated Muscovite responses in a manuscript form (see his paper in the present volume). ${ }^{28}$ Based on German printed editions, East Slavonic manuscript leechbooks featured translated text and drawings. Executed by Orthodox artists, these pictures reproduced German printed illustrations, including even nude anatomic figures. ${ }^{29}$

The exposure of the Palace collection to printed material suggests that we need to reassess the English traveller Jerome Horsey's claim that his copy of the Ostroh Bible printed by Ivan Fedorov (now in the British Library) originated from "the Emperotors library" (figs. 1-3). Scholars' characteristics of Horsey range from magniloquent (V.M. Du Feu and J.S.G. Simmons) to well-informed but deceitful, occasionally mendacious, not always trustworthy

\footnotetext{
${ }^{27}$ On European court physicians mediating between Western printed and Muscovite manuscript cultures, see Clare Griffin, The Production and Consumption of Medical Knowledge in Seventeenth-Century Russia: The Apothecary Chancery, PhD thesis (London: University College London, 2012).

${ }^{28}$ Franklin focuses primarily on seventeenth-century material, but asymmetrical responses to Western print culture are also detectable in Ivan IV's literary entourage. Asymmetrical engagements with print included a Slavonic translation of Marcin Bielski's Kronika (from a printed editions supplemented with Kosmographia) that was kept in the royal archive, and the Illustrated Chronicle Compilation (Litsevoi letopisnyi svod), which, in my view, was an ambitious hand-written response to Western printed cosmographies. Zimin, Gosudarstvennyi arkhiv, 92, 499-500; V.V. Morozov, Litsevoi svod v kontekste otechestvennogo letopisaniia XVI veka (Moscow: Indrik, 2005).

${ }^{29}$ Important examples of handwritten illustrated leechbooks include the 1534 and 1616 manuscripts. On the Muscovite origin of the 1534 manuscript, which is now in Kharkiv, see B.N. Morozov, "Travnik iz Postel'noi kazny Ivana Groznogo? Khar'kovskaia rukopis' 1534 g. - novyi pamiatnik knizhnoi masterskoi mitropolita Daniila," in Arkheograficheskii ezhegondik za 2002 god (Moscow: Nauka, 2004), 73-85; T.A. Isachenko, “lavliaetsia li Khar'kovskii spisok Travnika 1534 g. avtografom perevoda Nikolaia Biulova?" Drevniaia Rus'. Voprosy medievistiki (hereafter DR), 2 (36) (2009): 97-109. B.N. Morozov's assertion about the origin of the Kharkiv manuscript from Ivan IV's library is unsubstantiated. Still, both leechbooks indicate what kind of medical texts and illustrations were kept in the Palace collection under Ivan IV.
} 
(Edward Keenan). ${ }^{30}$ Like many assertions about Ivan IV's library, Horsey's dubious reputation among historians is based on the superficial treatment of evidence. Students are skeptical about his notation in the Ostroh Bible because they compare it with a Latin inscription on a calligraphic roll that Horsey presented to the Bodleian Library. The inscription in the scroll misattributes the document to Ivan IV's hand. However, that notation was written not by Horsey, but by the founder of the library Thomas Bodley. We do not know why Bodley made such a claim ${ }^{31}$. As for Horsey's Ostroh Bible, it contains two notations, one in English and one in Latin. The English notation has not been even fully read (part of its text is blacked out). Judging by what we can read with the naked eye, the English inscription is Horsey's own hand as evidenced by his signature (fig. 2). ${ }^{32}$ By "the Emperotors library" he obviously meant not Ivan IV's personal library, but the Palace collection because the Englishman did not claim that he received the book personally from the tsar. As we have seen, books from the Palace collection indeed circulated within a wider network of owners, readers and consumers, including foreigners. There is nothing improbable in Horsey's evidence.

Now to Ivan IV himself. Scholars agree that Muscovite royalty dictated to their secretaries and could write only occasionally because writing was generally beneath royal status. ${ }^{33}$ Differences appear in cultural assessments of this type of literacy. For most students, Ivan IV's prejudices against writing did not prevent him from interacting with book culture, including printing. Keenan rejected references to Ivan IV as a patron of printing in Ivan

\footnotetext{
${ }^{30}$ V.M. Du Feu, J.S.G. Simmons, "Early Russian Abecedaria in Oxford and London," Oxford Slavonic Papers, n.s. 3 (1970): 122; Edward L. Keenan, “The Tsar's Two Bodies," Canadian-American Slavic Studies, 51 (2017): 13 note 81 .

31 "The manuscript was presented to the Bodleian by that old (and magniloquent) Moscow hand, Sir Jerome Horsey, in 1604, and bears an optimistic endorsement by no less a person than Sir Thomas Bodley to the effect that it was written by 'lo. Basilidis himself'." Du Feu, Simmons, "Early Russian Abecedaria," 122. John Barnicot's speculation that Bodley was misinformed by Horsey is based only on Barnicot's perception of Horsey as a great fabricator and fantasizer. John Barnicot [Dzhon Barnikot], "Neizvestnyia russkiia staropechatnyia knigi, naidennyia v Anglii," in Vremennik Obshchestva druzei russkoi knigi, 4 (1938), 80. ${ }^{32}$ The Latin inscription in the bottom margin is not signed and may be executed by somebody else (fig.3). For initial reassessment of Horsey's evidence, see Bogatyrev, “Ostroh Bible," 707, 711-713.

${ }^{33}$ This practice is evidenced by a private letter from Ivan IV's father Vasilii III to his wife Elena Glinskaia. The letter was written by his secretary Trufan Il'in, but attached to it was a note in Vasilii's own hand intended for Elena (the note has not survived). M.A. Obolenskii, ed., Pis'ma russkikh gosudarei i drugikh osob tsarskago semeistva, 1 (Moscow: Universistetskaia tipograffia, 1848), 3-4, no. 1. Vasilii III's letter to Elena is now in the Russian State Library (Rossiiskaia gosudarstvennaia biblioteka), fond no. 928, delo no. 6, http://dlib.rsl.ru/viewer/01004921792\#?page=5, accessed 13 June 2016; lu.V. Ankhimiuk, "Materialy Drevlekhranilishcha v fondakh OR RGB," in lu.M. Eskin, ed., Pamiati Lukicheva (Moscow: Drevlekhranilishche, 2006), 709-710. A photographic copy of the manuscript confirms the accuracy of M.A. Obolenskii's publication. The paleography of the letter is consistent with its attribution to the hand of Vasilii III's secretary.
} 
Fedorov's colophons. In his view, Ivan was illiterate, because "true literacy in that time required a knowledge of Church Slavonic," which the tsar lacked. Dismissing printing in Muscovy as a failure, Keenan insisted that the acknowledgments of Ivan in the colophons were purely ceremonial. ${ }^{34}$

All speculations about Ivan IV's ability to read and to write are arguments from silence because there is no direct evidence of his literacy or illiteracy. This is why we need the approach the problem of his interaction with print from a different perspective. The relationship between literacy and patronage was not as straightforward as Keenan believed. In fact, the patronage of early printing involved different types of literacy, including, as Peter Lucas notes, the elementary "ability to absorb texts read aloud to the person concerned." ${ }^{35}$ This type of literacy was typical of literary connoisseurs who acted as lay patrons of the printing press. Lucas clarifies that this does not mean that literary connoisseurs could never write but they did not need to be able to write to be patrons of printing. ${ }^{36}$ These important observations shed a new light on the problem of Ivan IV's exposure to printed books. Early Muscovite printers published religious texts that were read during the liturgy. Such texts were undoubtedly familiar to every practicing Orthodox, including the tsar. As we saw, liturgical books were also among books kept in Ivan IV's bedchamber.

Ivan IV's engagement with printing was that of a royal connoisseur who invested his money and political power in a printing enterprise in exchange for several benefits. According to Lucas, patrons benefitted from printing because it enhanced their magnificence. By granting permission to use their names in printed books, patrons publicly demonstrated their status and interest in particular aspects of religion and culture. In case of royal patronage, personal magnificence was accompanied by strengthening the patron's prestige as a protector of true

\footnotetext{
${ }^{34}$ Edward L. Keenan, "Ivan the Terrible and Book Culture: Fact, Fancy, and Fog: Remarks on Early Muscovite Printing," Solanus, n.s. 18 (2004): 33-37. Keenan claimed that evidence of Vasilii III's "putative literacy" was insubstantial, but he was not aware of the manuscripts of Vasilii III's letters and treated their published texts inconsistently. Cf. Edward Keenan, "Ivan IV and the 'King's Evil': Ni maka li to budet?" Russian History, 20 (1993), nos. 1-4: 6 note 5; Keenan, "Ivan the Terrible and Book Culture," 35.

${ }^{35}$ Lucas, "Growth," 221.

${ }^{36}$ For example, Duke Georg of Saxony (r. 1500-1539) was a literate royal patron who directly contributed to printed Catholic editions, but he was exceptionally well educated by the standards of his time. See Christoph Volkmar, "Turning Luther's Weapons against Him: The Birth of Catholic Propaganda in Saxony in the 1520s," in Walsby, Kemp, The Book Triumphant, 126-128.
} 
religion among various groups of domestic and foreign readers, including novices and religious opponents. ${ }^{37}$ Appendix II lists Ivan IV's titles as they appear in printed editions produced during his lifetime. The editing of his titles in some printed books indicates that the acknowledgements of the tsar were meaningful elements of the printed text. Printers reproduced the image of Ivan IV as independent ruler of Great Russia and a custodian of Orthodox faith on a scale unmatched by scribes and chroniclers. Like other royal patrons of printing, Ivan IV enjoyed flattery, publicity and fame. He did not have to be a Noble laureate in literature to appreciate the usefulness of press.

Portable and numerous (compared to manuscripts), printed books travelled across political borders disseminating Ivan IV's flattering reputation as a ruler and believer. Ivan Fedorov praised the tsar as a patron of printing in books published both in Moscow and in L'viv, where the printer was free from Muscovite censorship. ${ }^{38}$ Ruthenian patrons of Orthodox printing were also receptive to this gratifying image of Ivan IV. In his foreword to the Ostroh Bible Prince Vasyl' -Kostiantyn Ostroz'kyi extolled Ivan IV for providing the Ruthenian Orthodox with an ancient Slavonic Bible, allegedly translated under St. Vladimir (in fact, probably the Bible of Archbishop Gennadii). ${ }^{39}$ Non-Muscovite owners of Ivan Fedorov's editions also associated Ivan IV with Orthodox printed books. A copy of the 1564 Apostol which made its way to the Commonwealth projected Ivan IV's image as a guardian of Orthodoxy not only through acknowledgement of his patronage in the colophon, but also through the design of its cover. ${ }^{40}$ Printed Orthodox books gave Ivan IV a positive public image, which was a valuable propagandistic asset when compared with the disturbing representation of him as a bloodthirsty tyrant in another type of printed media, German Flugschriften.

\footnotetext{
37 Lucas, "Growth," 227, 230. See also Parry, "Patronage," 174; John Walsh, "Literary patronage in Medieval England, 1350-1550," Library Review, 58 (2009), 6: 453.

${ }^{38}$ Apostol (L'viv: Ivan Fedorov, 1574), fol. 260 (Bodleian Library, Oxford, B.21.16.Th.). For a facsimile reproduction, see Tikhomirov, $U$ istokov, 237 plate 14.

39 Bibliia (Ostroh: Ivan Fedorov, 1581), fol. [3] (first sequence). The reference to St Vladimir's heritage helped Vasyl'-Kostiantyn Ostroz'kyi to promote an association between his patronage of Orthodox culture in Ostroh and the cult of St. Vladimir. See Viise, Culture, 204. Cf. Vasil' Ul'ianovs' kyi, Kniaz' Vasyl'-Kostiantyn Ostroz' kyi: istorychnyi portret u halereï predkiv ta nashchadkiv (Kyiv: Prostyr, 2012), 841.

${ }^{40}$ Copy from I.N. Tsarskii's collection in a sixteenth-century binding featuring the double headed eagle of a design consistent with the dating of the binding, an image of Ivan IV (now indecipherable, but still visible in the nineteenth century) and an inscription containing his title of tsar. The book was in Zabłudów in 1602. Nemirovskii, Vozniknovenie, 273-274; Nemirovskii, Ivan Fedorov i ego epokha, 94.
} 
Still, it would be too simplistic to reduce Ivan IV's patronage of printing to blunt propaganda. Patronage of early printing also had a religious aspect that helped patrons to achieve spiritual preferment and rewards in the afterlife. ${ }^{41}$ In cultural terms, Ivan IV's patronage of Orthodox printing served the same purposes as his sponsorship of church building and material aid to religious institutions: achieving salvation through supporting the church. Among Ivan IV's numerous donations to churches and monasteries we find a printed Gospel published by the anonymous press in about $1553 .{ }^{42}$

We should be therefore cautious about Nemirovskii's assertion that Ivan IV instigated the expulsion of Ivan Fedorov and Petr Mstislavets from Moscow between October 1565 and July 1568. The historian connects the exile of the printers with the alleged disgrace of Archpriest Amos of St. Nicholas in the Kremlin, where Ivan Fedorov served as a deacon. ${ }^{43}$ S.B. Veselovskii and R.G. Skrynnikov went even further by inferring that Amos became a victim of the Oprichnina terror. They identified Amos of St. Nicholas with a certain monk Alexander, former Archpriest Amos, mentioned in Ivan IV's memorial list of victims of the Oprichnina. $^{44}$

All these contentions are doubtful. The sources mention Amos from 1553 to 1558/59. During that period he managed lands which Ivan IV granted to St. Nicholas in memory of his uncle Prince lurii Ivanovich of Dmitrov, gave testimony at a heresy trial and participated in court ceremonies. ${ }^{45}$ In particular, together with Metropolitan Makarii, Amos baptized the last khan of Kazan Ediger in 1553. The editor of the Illustrated Chronicle Compilation (Litsevoi letopisnyi svod), who worked in the 1570s and early 1580s, revised the account of

\footnotetext{
${ }^{41}$ Lucas, "Growth," 230; Walsh, "Literary patronage," 453.

${ }^{42}$ Nemirovskii, Ivan Fedorov i ego epokha, 841.

${ }^{43}$ Nemirovskii, Vozniknovenie, 335-337; E.L. Nemirovskii, Ivan Fedorov, okolo 1510-1583 (Moscow: Nauka, 1985), 116; Nemirovskii, Ivan Fedorov i ego epokha, 788.

${ }^{44}$ S.B. Veselovskii, Issledovaniia po istorii oprichniny (Moscow: Izdatel'stvo AN SSSR, 1963), 356; R.G.

Skrynnikov, Nachalo oprichniny (Leningrad: Izdatel'stvo Leningradskogo universiteta, 1966), 33; R.G.

Skrynnikov, Oprichnyi terror (Leningrad: Izdatel'stvo Leningradskogo universiteta, 1969), 54 note 6, 278; R.G. Skrynnikov, Tsarstvo terrora (St. Petersburg: Nauka, 1992), 391 note 202, 537. The conjecture about the execution of Amos of St. Nicholas has resurfaced in a recent superficial biography of Ivan Fedorov: Tat'iana Murav'eva, Ivan Fedorov (Moscow: Molodaia gvardiia, 2011), 233.

${ }^{45}$ Polnoe sobranie russkikh letopisei (hereafter PSRL), 13 (Moscow: lazyki russkoi kul'tury, 2000), 230, 233, 250; S.N. Kisterev, L.A. Timoshina, eds., Materialy dlia istorii Zvenigorodskogo kraia, 1 (Moscow: Arkheograficheskii tsentr, 1992), 106-107.
} 
Ediger's baptism by replacing the name of Amos with that of Bishop Savva of Sarai and Don. For Nemirovskii this is a sign of royal disfavour (he accepts the dated view that Ivan IV edited the chronicle himself). However, there might have been other reasons for editorial intervention. The chronicle account of Ivan IV's campaigns against Kazan starts with Metropolitan Makarii and Bishop Savva blessing the tsar and finishes with Makarii and Savva baptising another captured Kazanian khan, Utemysh-Girei. ${ }^{46}$ By reattributing the baptism of Simeon to Savva the editor created a nicely rounded story about the same pair of clerics (Makarii and Savva) supporting Ivan IV's campaign against Kazan from its initial stage all the way to the triumphal conversion of both captured Kazanian rulers into Orthodoxy. The editor of the chronicle was therefore driven by literary rather than political considerations.

As for Ivan IV's memorial list, the above-mentioned Alexander-Amos appears in the section of the document that deals with the pogrom of Novgorod in 1570. Given its regional focus, the record almost certainly refers not to Amos of St. Nicholas in Moscow, but to another Amos, former archpriest of St. Sophia in Novgorod, whose homestead was sold by order of the local archbishop in $1577 .{ }^{47}$

On the whole, Ivan IV displayed no resentment towards Ivan Fedorov's publications or printing in general. Presses continued printing liturgical books in Moscow and in Ivan IV's residence at Aleksandrova Sloboda after Ivan Fedorov's and Petr Mstislavets' departure. Editions printed by Ivan Fedorov in the Commonwealth quickly penetrated different parts of Muscovy, including the tsar's palace in the Kremlin. ${ }^{48}$ Engaged in his Oprichnina extravaganza, the tsar did not offer the printers active protection to keep them in Moscow. But, as Ivan Fedorov's account of his expulsion from Muscovy explicitly says, Ivan IV was not among the printer's prosecutors. ${ }^{49}$

\footnotetext{
${ }^{46}$ PSRL, 13: 460, 527 notes 6-7.

${ }^{47}$ I.lu. Ankudinov and others, eds., Prikhodnaia kniga Sviatoi Sofii 1576/77 g. (Moscow, St. Petersburg: Al'iansArkheo, 2011), 9. That Archpriest Amos of St. Sophia, who became a victim of the massacre of Novgorod in 1570, should not be confused with another archpriest of St. Sophia of Novgorod, also called Amos, who defended the city from the Swedes in 1611. See P.V. Sedov, "Amos Ivanovich," in V.Ia. Ianin, ed., Velikii Novgorod. Istoriia i kul'tura IX-XVII vekov. Entsiklopedicheskii slovar' (St. Petersburg: Nestor-istoriia, 2007$), 70$.

${ }^{48}$ Bogatyrev, “Ostroh Bible," 707, 711-713.

${ }^{49}$ Apostol (L'viv: Ivan Fedorov, 1574), fol. 260.
} 


\section{Clerical Patronage}

Ivan Fedorov and Petr Mstislavets worked in Moscow during the tenures of two Metropolitans, Makarii (1542-1563) and his successor Afanasii (1564-1566). The patronage of printing brought these hierarchs the same benefits as those enjoyed by the tsar, prestige and spiritual elevation. However, Makarii's and Afanasii's engagement with religious book printing was based on a different type of literacy. Ivan IV's exposure to liturgical texts was hardly intensive enough for him to participate in editorial work or supervise the process of printing. His royal status also prevented him from engaging in such mundane activities. At the same time, like most clericals patrons of printing, Makarii and Afanasii were able to read and understand new texts as well as to write. ${ }^{50}$ They also had experience in managing largescale literary projects, which involved many copyists, scribes, and editors.

Scholars may have exaggerated Makarii's influence on court culture, but he was undoubtedly a key figure in Muscovite literature. His organizational skills are evidenced by his commission of a colossal collection of hand-written monthly readings (Velikie chetii minei). People from Makarii's entourage owned editions printed by the anonymous press in the 1550 s. $^{51}$ The information of the 1564 Apostol about Makarii's involvement in printing in the 1550 s is completely consistent with the metropolitan's activities during that period. At the same time, Makarii's role in the publication of the 1564 Apostol itself is less certain. The printing of the Apostol in Moscow is often seen as part of Makarii's ambitious cultural program. ${ }^{52}$ However, by the time Ivan Fedorov and Petr Mstislavets started printing the book on 19 April 1563, Makarii was already in his eighties and very sick. For a long time he

\footnotetext{
${ }^{50}$ Lucas, "Growth," 221. On this type of literacy, see also Gary Marker, "Literacy and Literacy Texts in Muscovy: A Reconsideration," Slavic Review, 49 (1990), 1: 76.

${ }^{51}$ Tikhomirov, "Nachalo knigopechataniia v Rossii," 25. For various appraisals of Makarii, see Makarii, arkhimandrit (Veretennikov), Zhizn' i trudy sviatitelia Makariia, mitropolita Moskovskogo i vseia Rusi (Moscow: Izdatel'skii sovet Russkoi pravoslavnoi tserkvi, 2002); Sergei Bogatyrev, "Reinventing the Russian Monarchy in the 1550s. Ivan the Terrible, the Dynasty, and the Church," The Slavonic and East European Review, 85 (2007), 2: 271-293. Michael S. Flier, "Golden Hall Iconography and the Makarian Initiative," in Kivelson et al., eds., The New Muscovite Cultural History, 63-75; Charles J. Halperin, "Metropolitan Makarii and Muscovite Court Politics during the Reign of Ivan IV," The Russian Review, 73 (2014): 447-64.

${ }^{52}$ K. Zaustsinskii, "Makarii Mitropolit vseia Rusi," Zhurnal Ministerstva narodnogo prosveshcheniia, 218 (November 1881): second pagination, 13, 16; A.S. Orlov, "K voprosu o nachale pechataniia v Moskve," in A.S. Orlov, ed., Ivan Fedorov pervopechatnik (Moscow, Leningrad: Izdatel'stvo AN SSSR, 1935), 18; I.V. Novosadskii, "Vozniknovenie pechatnoi knigi v Rossii v XVI veke," in Orlov, Ivan Fedorov, 39; Makarii (Veretennikov), Zhizn', 237; Biblioteka literatury Drevnei Rusi, 12 (St. Petersburg: Nauka, 2003), 538 (commentaries to Makarii's works by N.F. Droblenkova); Usachev, "Pervye russkie," 65 note 1.
} 
had suffered from injuries he received during the fire of Moscow in 1547. He stopped participating in diplomatic relations in November 1562. Throughout the year of 1563 Makarii kept his ceremonial duties to a minimum. He died in December of that year. ${ }^{53}$

Makarii's intellectual activities during that period were also at their lowest. He failed to write any work or speech in connection with Ivan IV's taking of Polatsk in February 1563, a major victory which Muscovite sources compared to the taking of Kazan. ${ }^{54}$ The only piece of writing produced by Makarii in 1563 was in fact his farewell letter, a standard text which could have been prepared in advance by Makarii himself or jotted down by somebody from the metropolitan's entourage during his terminal illness. Speaking of Makarii's immediate circle, it lost two important members throughout 1563: Makarii's treasurer Archimandrite Kassian died in April, and his long-time secretary Vasilii Vorob'ev passed away in May. ${ }^{55}$ Coupled with Makarii's poor health, the loss of important associates hindered the metropolitan's cultural work, including his patronage of printing. According to G.I. Koliada, who closely studied the texts of books printed by Ivan Fedorov and Petr Mstislavets in Moscow, Makarii's illness prevented him from participating in those publications. ${ }^{56}$ This is why the masters were very careful in their account of Makarii's contribution to printing in the colophon of the 1564 Apostol. The printers acknowledged Makarii's part in the establishment of the anonymous printing press in the 1550s, but, as apparent from the quote at the beginning of this paper, attributed the foundation of the press that printed the Apostol in 1563-64 exclusively to Ivan IV without mentioning Makarii. ${ }^{57}$

\footnotetext{
${ }^{53}$ Makarii met Ivan IV after his triumphal campaign against Polatsk in Moscow on 21 March, ordained a new archbishop of Polatsk in April, and interceded before Ivan for disgraced Vladimir of Staritsa and his mother Efrosinia before 5 August. A later source reports that Makarii caught cold during a procession on 15 September. In late November Makarii was already so weak that he could not attend the funeral of Ivan IV's brother lurii, who died on 24 November. PSRL, 13: 365, 366, 368, 372; Makarii (Veretennikov), Zhizn', 195, 284, 285.

${ }^{54}$ See Sergei Bogatyrev, "Battle for Divine Wisdom: The Rhetoric of Ivan IV's Campaign against Polotsk," in The Military and Society in Russia, 1450-1917, ed. Eric Lohr and Marshall Poe (Leiden: Brill, 2002), 325-363.

${ }_{55}$ Makarii, arkhimandrit (Veretennikov), "Zametki o mitropolite Makarii," Al'fa i Omega, 19 (1999), http://www.pravmir.ru/zametki-o-mitropolite-makarii/ (accessed 27 August 2016).

${ }^{56}$ G.I. Koliada, "Rabota Ivana Fedorova nad tekstami Apostola i Chasovnika i vopros o ego ukhode v Litvu," Trudy Otdela drevnerusskoi literatury (hereafter TODRL), 17 (1961), 244.

57 "Blagovernyi zhe tsar' povele oustroiti dom ot svoeia tsarskiia kazny, ide zhe pechatnomu delu stroitisia." Apostol (Moscow: Ivan Fedorov, Petr Timofeev Mstislavets, 1564), fol. 260v.
} 
The dating system employed in the colophon of the Apostol also neglects Makarii. Ivan Fedorov and Petr Mstislavets started working on the edition on 19 April 1563 when Makarii still occupied the metropolitan see. However, they disassociated the initial stage of the project from Makarii's tenure. The colophon dates the beginning of work on the book by the year from the Creation, but not by the regnal year of Makarii. This format is in sharp contrast with that of the date indicating the completion of the edition on 1 March 1564: the printers linked the end of work with Metropolitan Afanasii by giving the year of his tenure. This dating pattern is unique: as Appendix I shows, this is the only instance in Ivan Fedorov's editions when he dated an event exclusively by the regnal year of a metropolitan without mentioning the reign of the tsar.

Students of the 1564 Apostol have been harsh to Afanasii, denying him any literary activities and even claiming that he is not mentioned in the 1564 colophon at all. ${ }^{58}$ These assertions are of course ill-advised. Afanasii was responsible for the compilation of a major literary work, the Book of Degrees of the Royal Genealogy (Kniga stepennaia tsarskogo rodosloviia). He had been close to Ivan IV since 1550 when the cleric (then under his baptismal name of Andrei) became the archpriest of the Annunciation Cathedral in the Moscow Kremlin and the confessor of the tsar. Andrei participated in the Kazan campaign of 1552. He took monastic vows under the name of Afanasii in the Chudov monastery in the Kremlin in 1562. On 24 February 1564 Afanasii was selected metropolitan, followed by his installation on 5 March. Contrary to a widespread misconception, Afanasii's retirement on 19 May 1566 was not a political demonstration of his disapproval of the Oprichnina, but an act of personal salvation caused by his deteriorating health. After his resignation Afanasii retained his position of authority in the arts and letters until his death (between 1567 and 1575). This is evidenced by the royal commission of Afanasii to renovate the most prestigious icon of the Vladimir Mother of God in 1567 and a positive retrospective reference to the metropolitan as a patron of printing in the Psalter published in Moscow in 1568 (see below). As mentioned above, a Euchologion from Afanasii's library or scriptorium was kept in Ivan IV's palace. $^{59}$

\footnotetext{
${ }^{58}$ Orlov, “K voprosu," 18; Usachev, "Pervye russkie," 65 note 1.

${ }^{59}$ On Afanasii, see A.S. Usachev, “Mitropolit Afanasii i Psaltir' 1568 g.,” Vestnik arkhivista, 3 (2013): 20-29; Sergei Bogatyrev, "The Resignation of Metropolitan Afanasii in 1566," Canadian-American Slavic Studies, 49
} 
M.N. Tikhomirov, who seems to be the only scholar to point out the connection between the 1564 Apostol and Afanasii, noted that the colophon of the book calls him metropolitan despite the fact that he was not yet officially installed in his office by the time the edition was completed on 1 March 1564. According to Tikhomirov, Ivan Fedorov intended the book as a gift for Afanasii, who probably acted as locum tenens under the now incapable Makarii. ${ }^{60}$ Indeed, not only did the printer refer to Afanasii as metropolitan in the colophon, but also gave the hierarch one more title, that of archbishop, as opposed to his predecessor Makarii, who received only the title of metropolitan in the colophon. ${ }^{61}$ On the whole, the chronological records in the 1564 Apostol indicate that the printers were shifting their loyalties from Makarii to Afanasii trying to secure the patronage of the incoming head of the Orthodox church.

Afanasii himself may have had particular reasons for supporting printing. By enhancing his magnitude through patronage he addressed the delicate problem of his background. B.A. Uspenskii has noted that metropolitans usually came from the ranks for bishops or abbots. Afanasii was the first metropolitan in the Rus' autocephalous church holding no administrative post in the church hierarchy prior to his installation. ${ }^{62}$ Uspenskii, however, has not developed his observations far enough. Afanasii's non-episcopal status explains his active cultural policies, which historians often misinterpret as nothing more than a continuation of Metropolitan Makarii's activities. In fact, Afanasii was much more inventive in his cultural work than Makarii. ${ }^{63}$

Afanasii's ascension to the metropolitan see was accompanied by revisions to the ritual of installation of a newly elected metropolitan. Scholars usually reduce these revisions to the

(2015): 174-192 and literature quoted in these works. On Afanasii's Euchologion, see “Opis' domashnemu imushchestvu," 6.

${ }^{60}$ Tikhomirov, "Nachalo knigopechataniia v Rossii," 34; M.N. Tikhomirov, "Nachalo moskovskogo knigopechataniia," in M.N. Tikhomirov, Russkaia kul'tura X-XVIII vekov (Moscow: Nauka, 1968), 398, 407.

${ }^{61}$ On the title of archbishop, see B.A. Uspenskii, Tsar' i patriarkh. Kharizma vlasti v Rossii: Vizantiiskaia model' vlasti i ee russkoe pereosmyslenie (Moscow: Shkola "lazyki russkoi kul'tury," 1998), 462-467; Vladislav Tsyplin, "Arkhiepiskop," in Pravoslavnaia entsiklopediia: http://www.pravenc.ru/text/76484.html (accessed 27 June 2016).

${ }^{62}$ On Afanasii's unique status, see Uspenskii, Tsar' i patriarkh, 76 note 79.

${ }^{63}$ For a reassessment of Afanasii, see Bogatyrev, "Resignation." 
introduction of a new headgear for the metropolitan, a white cowl, i.e. the same headgear that the archbishop of Novgorod wore. It is assumed that Makarii, who was archbishop of Novgorod before becoming metropolitan, continued wearing a white cowl even when he became metropolitan; the revised ritual of installation validated this practice after his death. ${ }^{64}$ However, changes in the ceremony focused not on continuing Makarii's practices, but on preparing a background for Afanasii's installation. The ritual of installation was updated to accommodate a candidate from the ranks of spiritual elders, i.e. a candidate coming from the same background as Afanasii did. The revised version of the ceremony also omitted the traditional rite of unification (obriad soedineniia) when the candidate exchanged kisses with the bishops, something which suggest that some bishops could have been contemptuous of Afanasii. ${ }^{65}$ In this context, the new symbolism of the metropolitan's power, including a white cowl, was supposed to demonstrate that the head of the church was superior to all bishops. ${ }^{66}$ Such preoccupation with the public image of the metropolitan explains Afanasii's engagement with printing: his patronage of Ivan Fedorov's press enhanced Afanasii's prestige by associating his name with the successful completion of the 1564 Apostol.

Afanasii apparently took a keener interest in printing than Makarii, not to mention Ivan IV. Clerical patrons were often responsible for what is known as selection, i.e. commissioning works on particular subjects. ${ }^{67}$ There is no direct evidence of how Muscovite printers chose

\footnotetext{
${ }^{64}$ Uspenskii, Tsar' i patriarkh, 429. Archimandrite Makarii (Veretennikov) speculates that the revision of the ritual was a step towards the establishment of patriarchate in Russia, but nothing in the sources supports this view. Makarii (Veretennikov), Zhizn', 304-305.

${ }^{65}$ Akty, sobrannye v bibliotekakh i arkhivakh Rossiiskoi imperii Arkheograficheskoiu ekspeditsieiu (hereafter, AAE), 1 (St. Petersburg: Tipografiia II Otdeleleniia SEIV kantseliarii, 1836), no. 264: 297, 298, 299; Paul Bushkovitch, "The Selection and Deposition of the Metropolitan and Patriarch of the Orthodox Church in Russia, 1448-1619," in Marek Derwich, Mikhail V. Dmitriev, eds., Etre catholique - être orthodoxe - être protestant: confessions et identités culturelles en Europe médiévale et modern (Wrocław: Larhcor, 2003), 136, 144. On the ritual of kissing with bishops, see $A A E, 1$, no. 184: 159. The edition in $A A E$ is apparently based on the manuscript no. 107 from the Stroev collection. N. Barsukov, Zhizn' i trudy P.M. Stroeva (St. Petersburg: Tipografiia V.S. Balasheva, 1878), 378. On the origin of Stroev's miscellanies, see D.K. Uo (Daniel Waugh), “K izucheniiu istorii rukopisnogo sobraniia P.M. Stroeva," TODRL, 30 (1976), 184-203; 32 (1977), 133-164.

${ }^{66}$ PSRL, 13: 378-380. Skrynnikov was correct that these measures were aimed at elevating the status of the metropolitan rather than diminishing the position of the archbishop of Novgorod, as A.A. Zimin and A.L. Khoroshkevich thought. Indeed, it was dangerous to alienate the bishops because it was their exclusive prerogative to install a new metropolitan. Skrynnikov, Tsarstvo, 179; A.A. Zimin, Oprichnina (Moscow: Territoriia, 2001), 81, 315 note 121; A.L. Khoroshkevich, "Mitropolit Afanasii i tsar' Ivan Groznyi," in In Memoriam. Sbornik pamiati la.S. Lur'e (St. Petersburg: Atheneum-Feniks, 1997), 285.

67 Lucas, "Growth," 230.
} 
titles for publishing. As a deacon, Ivan Fedorov was perfectly familiar with the Apostol as it is one of the deacon's responsibilities to read from that book during the liturgy. ${ }^{68}$ Still, Afanasii also had an advanced knowledge of that text because he copied a commented handwritten version of the Apostol (Tolkovyi Apostol). ${ }^{69}$ As a patron, he could therefore offer Ivan Fedorov not only administrative and spiritual supervision, but also literary expertise.

The patronage of an expert was a mixed blessing for a printer. Such a patron was able to contribute to the preparation of an edition, but could also interfere in work in progress (this aspect of patronage is called stipulation). ${ }^{70}$ At some time before his resignation on 19 May 1566 Afanasii commissioned the Psalter from two new printers, Nikifor Tarasiev and Nevezha Timofeev, who completed the book in $1568 .{ }^{71}$ This commission is important for our understanding of the reasons for Ivan Fedorov's and Petr Mstislavets' departure from Moscow. ${ }^{72}$ Afanasii hired two new printers around or soon after the time that Ivan Fedorov and Petr Mstislavets finished printing the second edition of the Book of Hours in Moscow on 29 October 1565.

As we can see, Afanasii was able to employ four printers within a short period from the second half of 1565 to the first half of 1566 . This indicates an oversupply of technical expertise, resulting in the growing number of printers competing for the few printing jobs in the capital. A low flow of orders caused masters to move even in Europe, where demand for printed books was considerably higher than in Muscovy. ${ }^{73}$ Printers operating on the underdeveloped market of printed matters in Moscow faced even tougher completion for

\footnotetext{
${ }^{68}$ Diakon Mikhail Zheltov, “Diakon,” Pravos/avnaia entsiklopediia: http://www.pravenc.ru/text/171911.html (accessed 27 June 2016).

${ }^{69}$ B.M. Kloss, Nikonovskii svod i russkie letopisi XVI-XVII vekov (Moscow: Nauka, 1980), 263 note 133. See also A.S. Usachev's article in this collection.

${ }^{70}$ On stipulation, see Lucas, "Growth," 231.

${ }^{71}$ Iu.A. Labyntsev, Tipografiia Nikifora Tarasieva i Nevezhi Timofeeva (Svodnyi katalog i opisanie staropechatnykh izdanii kirillovskogo i glagolicheskogo shriftov. Opisanie staropechatnykh izdanii kirillovskogo shrifta, 19, Moscow: Gos. biblioteka im. V.I. Lenina, 1984), 9 (editor's foreword), 29-30 (facsimile reproduction); Usachev, "Mitropolit Afanasii i Psaltir"," 24; Voznesenskii, $K$ istorii, 265-266.

${ }^{72}$ On possible dates of the printers' departure, see B.V. Sapunov, "K voprosu o prekrashchenii deiatel'nosti pervykh tipografii v Moskve," TODRL, 12 (1956), 436 (winter 1566-1567); Koliada, "Rabota," 254 (second half of 1566); R.G. Skrynnikov, Gosudarstvo i tserkov' na Rusi XIV-XVI vv. Podvizhniki russkoi tserkvi (Novosibirsk: Nauka, 1991), 275 (July 1566). For earlier dates, see Nemirovskii, Ivan Fedorov v Belorussii, $69-70$ (late autumn or early winter of 1565); Usachev, "Mitropolit Afanasii i Psaltir'," 28 note 16 (from 29 October 1565 to 16 May 1566).

${ }^{73}$ Eisenstein, Printing Press, 58; Viise, "Culture," 54.
} 
orders and patronage. Despite unverifiable assertions that Nikifor Tarasiev and Nevezha Timofeev were Ivan Fedorov's apprentices, it remains unclear whether the paths of two teams crossed in Moscow before Ivan Fedorov's and Petr Mstislavets' departure. ${ }^{74}$ What is obvious is that Nikifor Tarasiev and Nevezha Timofeev failed to mention Ivan Fedorov in the colophon of their Psalter; they did not inherit his printing equipment, though the design of decorative elements in their edition copied Ivan Fedorov's patterns. ${ }^{75}$ Ivan Fedorov also remained silent about his successors in Moscow in his colophons. At the same time, he printed his Psalter in Zabłudów (Appendix I, no. 5) very soon after Nikifor Tarasiev's and Nevezha Timofeev's Psalter appeared in Moscow. The two teams of printers were thus capable of producing the Psalter and could compete for Afanasii's order for a printed edition of the book.

Both groups of masters were associated with Afanasii, but their recollections of the metropolitan were completely different. Nikifor Tarasiev and Nevezha Timofeev acknowledged Afanasii for two years after his resignation. On the contrary, Ivan Fedorov's account of the history of printing included in the 1574 Apostol completely omits Afanasii's patronage, despite the fact that the printer published all his Moscow editions during Afanasii's tenure as metropolitan. Despite their flattering references to the hierarch in the 1564 Apostol, it looks as if Ivan Fedorov and Petr Mstislavets eventually lost the metropolitan's favor.

The defining event in their relationship with the patron was Ivan Fedorov's and Petr Mstislavets' publication of the Book of Hours. Printed in Moscow between 7 August and 29 September 1565, the first edition of the book, which has survived in only one copy, is marred with numerous textual and typographical errors. The quality of the edition was so poor that the printers had to start a new corrected edition of the Book of Hours (Appendix I, no. 3) even before finishing the first one. ${ }^{76}$

\footnotetext{
${ }^{74}$ On Nikifor Tarasiev and Nevezha Timofeev as Ivan Fedorov's pupils, see Nemirovskii, Ivan Fedorov i ego epokha, 540, 545. Labyntsev is skeptical about this assertion. See Labyntsev, Tipografiia, 5.

${ }^{75}$ Labyntsev, Tipografiia, 9, 11.

${ }^{76}$ See Nemirovskii, Ivan Fedorov i ego epokha, 794-799.
} 
Scholars have offered various explanations for the low quality of the first edition of the Book of Hours. Koliada hypothesized that it was a private order. However, it remains unclear why a private commission had to be so bad, so this conjecture is now rejected. ${ }^{77}$ It has also been suggested that the printers rushed the edition in response to a high demand for the Book of Hours which served both as a devotional and pedagogical text. It is true that the Book of Hours was used in schooling, although it required some pre-existing literacy, which pupils usually received from primers. ${ }^{78}$ At the same time, the assertion that the masters worked on the first edition under time pressure is contradicted by the fact with during the printing of that edition they found the time to prepare a new corrected edition of the Book of Hours.

The prompt appearance of the second edition of the book suggests that the reason for the low standards of the first edition was not haste, but negligence. The printers apparently slacked off after finishing the pilot edition of the Apostol in 1564. A.I. Rogov seems to idealize Ivan Fedorov by assuming that the printer initiated the second edition because he could not tolerate the bad quality of the previous edition. ${ }^{79}$ Most likely, the new corrected edition resulted from the intervention of a patron. M.V. Kukushkina correctly links the second edition with Afanasii, who is acknowledged in the chronological notes of both editions of the Book of Hours. ${ }^{80}$

Editorial changes in the Moscow editions of the Book of Hours reflected concerns about the status of the tsar, his relationship with the church and the morale of Muscovite society. The second edition put additional emphasis on the figure of the Muscovite tsar in the prayers included in the book. ${ }^{81}$ The colophon of the second edition also corrected the previous edition's blunders in important public statements. In particular, the first edition omitted an

\footnotetext{
${ }^{77}$ Koliada, “Rabota," 239. For a criticism of Koliada's assertion, see A.V. Voznesenskii, "K voprosu o formate moskovskikh Chasovnikov Ivana Fedorova i Petra Timofeeva Mstislavtsa," Ocherki feudal'noi Rossii, 15 (2012), 193 note 1.

${ }^{78}$ A.I. Rogov, "Vozniknovenie i razvitie knigopechataniia," in A.V. Artsikhovskii, ed., Ocherki russkoi kul'tury XVI veka, 2 (Moscow: Izdatel'stvo Moskovskogo universiteta, 1977), 274; Murav'eva, Ivan, 230. On the hierarchy of pedagogical texts in Muscovy, see Marker, "Literacy," 77.

${ }^{79}$ Rogov, "Vozniknovenie," 274. In line with Rogov's view, Isaevych speculates that the printers paid for both editions of the Book of Hours out of their own pockets. Isaevych, Literaturna spadshchyna, 67.

${ }^{80}$ Kukushkina, Kniga, 164.

${ }^{81}$ Koliada, "Rabota," 239-242.
} 
invocation to God to stop evil acts among people. The editor of the second edition restored that declaration, which was very significant in the context of the Oprichnina terror. ${ }^{82}$

The first edition also truncated the title of Ivan IV by omitting the words "autocrat of All Great Russia" (Appendix II, nos. 4a, 4b). ${ }^{83}$ Ivan IV and his entourage had been sensitive to the issue of titles from the time of his coronation as tsar in 1547 because Ivan's main foreign adversary, the king of Poland, did not recognize the new imperial title of the Muscovite ruler. Charles Halperin has demonstrated that the term autocrat, meaning an independent, pious and unlimited ruler, was not a permanent element of Ivan IV's title. ${ }^{84}$ As Appendix II shows, Ivan Fedorov and other Muscovite printers indeed used a variety of royal titles ranging from one word to extensive rhetorical constructions, often without "autocrat." However, there is a reoccurring pattern in the use of this term in early printed editions: the colophons of all books printed in Muscovy under Ivan IV call him "autocrat" when they mention the tsar for the first time, with the only exception of the first edition of the Books of Hours (Appendix II, nos. 1, 4b, 7, 10, cf. 4a). This practice goes back to the colophon of the 1564 Apostol, which used "autocrat" in conjunction with the unusual expression "All Great Russia" (Autocrat of All Great Russia). This construction reflects the influence of epistles of Eastern Orthodox patriarchs to the tsar. The Book of Degrees, which, as mentioned above, was a product of Afanasii's patronage, reproduces one of such epistles. ${ }^{85}$ What is even more significant is that "Autocrat of All Great Russia" appears only in books that were printed or conceived under the patronage of Afanasii (Appendix II, nos. 1, 4b, 7). At the same time, this title is absent from editions that had no connections with Afanasii, like Ivan Fedorov's Apostol printed in L'viv and the 1577 (the latter mentions all Rus', but not Great Russia, Appendix ii, nos. 3, 6, 10).

\footnotetext{
${ }^{82}$ Demin, "Russkie poslesloviia," 69 note 74.

${ }^{83}$ A.S. Zernova, "Knigi kirillovskoi pechati, khraniashchiesia v zagranichnykh bibliotekakh i neizvestnye v russkoi bibliografii," in Trudy [Gosudarstvennoi biblioteki SSSR im. V.I. Lenina], 2 (Moscow: Gos. ordena Lenina biblioteka SSSR im. V.I. Lenina, 1958), 10.

${ }^{84}$ Charles J. Halperin, "Ivan IV as Autocrat (Samoderzhets)," Cahiers du Monde russe, 55 (2014), 3-4: 197-213.

${ }^{85}$ S.M. Kashtanov, ed., Rossiia i Grecheskii mir v XVI v., 1 (Moscow: Nauka, 2004), 235, 259, 261, 265; N.N. Pokrovskii, G.D. Lenhoff, eds., Stepennaia kniga tsarskogo rodosloviia po drevneishim spiskam, 2 (Moscow: lazyki slavianskikh kul'tur, 2008), 394. For a textual analysis of this passage, which is crucial to the dating of the Book of Degrees, see S.N. Bogatyrev, “Datirovka Stepennoi knigi," DR, 4 (50) (2012): 84, 89-90.
} 
The revision of the first edition of the Book of Hours thus indicates Afanasii's involvement in the project. He was deeply engaged with issues addressed by the editor of the second edition. His Book of Degrees dealt with the relationship between the crown and the church. ${ }^{86}$ After the establishment of the Oprichinina the metropolitan mediated between the tsar and those accused of treason, including the clergy. It was the metropolitan's obligation to denounce the excesses of the Oprichnina, but in a cautious manner that would not alienate the raging tsar. This explains why he restored the passage about eliminating evil among people in the second edition.

Afanasii also insisted on the use of the title of Autocrat of All Great Russia in the opening statements of the colophons of printed editions, including the Book of Hours. This title usually follows passages about the divine inspiration of printing and therefore refers to Ivan IV's piety which enabled him to fulfill God's will by supporting press. Taken together with "All Great Russia," the term "autocrat" both reminded Ivan IV of piousness and extolled him as Orthodox tsar, a rhetorical devise typical of Afanasii's respectful, but purposeful attitude to the monarch. ${ }^{87}$ Afanasii therefore had good reasons to be concerned about the first edition of the Book of Hours: it distorted prayers and statements that were relevant to his spiritual mission and public stance. The second edition therefore resulted from Afanasii's intervention (stipulation) in the work of Ivan Fedorov and Petr Mstislavets.

Ivan Fedorov and Petr Mstislavets responded to Afanasii's intervention by appealing to the authority of Ivan IV and the memory of Metropolitan Makarii. In the colophons of both editions of the Book of Hours, the printers acknowledged the tsar and Makarii as their patrons to counterbalance the compulsory references to Afanasii. The colophons attribute the establishment of Ivan Fedorov's and Petr Mstislavets' press not only to Ivan IV, as the 1564 Apostol did, but also to Metropolitan Makarii. The printers thus claimed the memory of Makarii for their own purposes. At the same time, they completely avoided the establishment of the anonymous press, as this subject was irrelevant to the agenda of the

\footnotetext{
${ }^{86}$ The exact dating of the Book of Degrees, which, in my view, was created during Afanasii's tenure as metropolitan, is irrelevant here. For various dates, see Bogatyrev, "Datirovka;" A.S. Usachev, "Vremia sozdaniia Stepennoi knigi: v prodolzhenie diskussii," DR 1(51) (2013): 115-124; Bogatyrev, “Resignation," 179 note 17.

${ }^{87}$ On Afanasii's use of cultural mechanisms for promoting an agenda in his relations with the tsar, see Bogatyrev, "Resignation."
} 
colophons of the Book of Hours. The dating system was also altered to demonstrate that the printers enjoyed not only the patronage of Afanasii, but also the patronage of the tsar. Unlike the 1564 Apostol, which promotes Afanasii in its chronological records, the colophons of the Book of Hours relegates his name to a secondary position by introducing the regnal year of Ivan IV (with an error, see above). As a result of this manipulation of the chronological records, the two editions of the Book of Hours are the only publications of Ivan Fedorov that feature triple dates: AM year, the regnal year of Ivan IV, and the regnal year of Afanasii (Appendix I, nos. 2, 3). ${ }^{88}$

The purpose of this excessive formalization was to validate the problematic editions of the Book of Hours by acknowledging as many patrons of printing as possible, both living and deceased. But this scheme did not work. Though the new edition of the Books of Hours corrected some errors of the first edition, it also introduced new mistakes. ${ }^{89}$ The unfortunate and costly experience with printing the Book of Hours apparently caused Afanasii to fire Ivan Fedorov and Petr Mstislavets and to employ new masters, Nikifor Tarasiev and Nevezha Timofeev. Deprived of the metropolitan's patronage, Ivan Fedorov and Petr Mstislavets had to leave Moscow for the Grand Duchy of Lithuania, though they were given time to pack their printing equipment. ${ }^{90}$ The printers' departure from Moscow was indeed caused by their professional activities, as Demin and other scholars suggested. However, it was not cultural prejudices against printing in Muscovy, but the poor quality of their editions that was the main reason for the printers' departure.

\footnotetext{
${ }^{88}$ Chasovnik, 1st edn., [fols. 172-173]; Chasovnik, 2nd edn., [fol. 171v].

${ }^{89}$ See Nemirovskii, Vozniknovenie, 316.

${ }^{90}$ Zernova, Nachalo, 43-46. Most studies argue that the printers left Moscow under the pressure of alleged enemies of Ivan IV, but this view too heavily relies on the old idea the tsar faced opposition from some "reactionary feudal circles." Theories that the printers left because of competition with scribes or were secretly sent to Lithuania by Ivan IV do not stand up to scrutiny. Novosadskii, "Vozniknovenie," 57-58; Tikhomirov, "Nachalo knigopechataniia v Rossii," 36-37; Sapunov, "K voprosu," 439-440; Koliada, "Rabota," 246; Skrynnikov, Nachalo oprichniny, 331-333; For a critical assessment of these views, see Nemirovskii, Vozniknovenie, 333-340. Demin believed that the printers fled for the Grand Duchy because Muscovites distrusted printed books, in particular the 1564 edition of the Apostol, but this assertion is dated. Demin, "Russkie staropechatnye poslesloviia," 47, 59, 66.
} 


\section{Recollecting Muscovite Patrons}

In Ruthenia, Ivan Fedorov had to accommodate a new pattern of patronage that was based on the intricate network of Orthodox magnates, successful traders and urban communities. It was a long process that required a cultural adjustment, as apparent from the first edition printed by Ivan Fedorov and Petr Mstislavets in the Grand Duchy of Lithuania, the Homiliary Gospel (Zabłudów, 1569). The book features a title page, an element unknown in Muscovite book culture, but typical of Western printed editions. Still, the format of the title page is underdeveloped, an indicator of the transitional position of the Homiliary Gospel between Muscovite and Western traditions of book printing. ${ }^{91}$

The printers' acknowledgement of patronage is also a mixed bag. On the one hand, they praised their new Ruthenian patron, Hryhorii Khodkevych. At the same time, the title page still contains a regnal note mentioning Sigismund II August and Metropolitan Iona of Kyiv and Halych (Appendix I, no. 4). ${ }^{92}$ This appellation to the king and the hierarch, neither of whom had anything to do with the Zabłudów edition, echoes the printers' experience in dealing with royal and clerical patrons in Moscow. Ivan Fedorov abandoned the practice of acknowledging the royal and ecclesiastical leaders of the Commonwealth as he became integrated into Ruthenian society. Consequently, regnal years and notes gradually disappeared from the dating systems of his editions printed later in the Grand Duchy (see Appendix I). ${ }^{93}$

Ivan Fedorov recollected his Muscovite patrons in the colophon of a new edition of the Apostol that he printed in L'viv in 1574. According to Michelle Ruth Viise, the decision to republish the Apostol, which already received royal sanction in Moscow, suggests that Ivan Fedorov tried to play safe by avoiding "the risk of producing a book that met with his patron's disapproval." He may have also hoped that the tsar's validation would guarantee

\footnotetext{
${ }^{91}$ Nemirovskii, Ivan Fedorov v Belorussii, 108; Viise, Culture, 48.

${ }^{92}$ Nemirovskii, Ivan Fedorov i ego epokha, 10 (facsimile). On Metropolitan Iona III, see V.I. UI' ianovs' kyi, Istoriia tserkvy ta relihiinoi dumky v Ukraini, 1 (Kyiv: Lybid', 1994), 70-72.

${ }_{93}$ Petr Mstsilavets reintroduced a regnal note acknowledging King Henry and Metropolitan lona in his first edition published in the Grand Duchy, apparently following his and Ivan Fedorov's Moscow printing practice. Evangelie (Vilnius: Petr Mstislavets, 1575), fol. 394. British Library C.104.k.15. On Petr Mstislavets leaning on Ivan Fedorov's models, see Viise, Culture, 76-81.
} 
distribution of the new edition. However, he failed to take into account the low demand for printed Church Slavonic works in the L'viv Orthodox community, which was more concerned about rebuilding after a resent devastating fire. ${ }^{94}$ Without knowledge of the PolishLithuanian book market, and probably without a patron, Ivan Fedorov tried to create a network of patronage among the citizens of L'viv by publishing an appealing literary story. The colophon of the 1574 Apostol, which is usually seen as a reliable historical account of early printing, is in fact a dramatized tale about Ivan Fedorov's sufferings based on a hagiographical model. Ivan Fedorov's account of misfortune, which took him from one place to another, was supposed to prove the holiness of his calling and attract potential patrons. ${ }^{95}$

According to the 1574 colophon, despite all the troubles Ivan Fedorov was determined to continue his spiritual mission which he started in Moscow. This is why he was eager to stress that the press that produced the L'viv Apostol was the same press that was established by Ivan IV and blessed by Makarii. ${ }^{96}$ In this respect the 1574 colophon develops a revised story of the Moscow press that Ivan Fedorov already employed in the Moscow editions of the Book of Hours. At the same time, the printer ignored details that might have spoiled the story of his suffering: the colophon of the L'viv Apostol conveniently omits the names of Metropolitan Afanasii and Petr Mstislavets, who might have become Ivan Fedorov's competitor in the Grand Duchy. ${ }^{97}$ This background explains why Ivan Fedorov's account of his departure from Moscow is so vague. His claim that Ivan IV was not among his persecutors was correct. The printer's unspecified references to leading officials and hierarchs and some teachers who were envious with Ivan Fedorov may refer to Afanasii and his entourage. At the same time, the printer's description of his Muscovite adversaries as immoral, ignorant, unwise men who were neither skilled in the art of letters nor filled with spiritual wisdom should be treated with caution: Ivan Fedorov had good reasons to conceal his own sloppy work in Moscow.

\footnotetext{
${ }^{94}$ Viise, Culture, 112-114, 135.

${ }^{95}$ Viktoriia Kolosova, “Ukrains'ki starodruky i kyrylo-mefodiivs'ka tradytsiia. Literaturoznavchyi aspekt: Na materiali Pisliamovy Ivana Fedorova do I'vivs'koho Apostola 1574 r.," in Jerzy Rusek and others, eds., "Najstarsze druki cerkiewnosłowiańskie i ich stosunek do tradycji rękopiśmiennej": Materiały z sesji, Kraków 710 XI 1991 (Kraków: Instytut Filologii Słowiańskiej 1993), 211-219; Viise, Culture, 122, 124, 125, 133-137.

${ }^{96}$ The colophon opens with a statement: 'This is a tale about where this press (drukarnia siia) started from and how it was established.' Apostol (L'viv: Ivan Fedorov, 1574), fol. 260. See Isaevych, Literaturna spadshchyna , 101; Kolosova, "Ukrains'ki starodruky," 214.

${ }^{97}$ On possible competition between Petr Mstislavets and Ivan Fedorov, see Viise, Culture, 30, 38 note 83.
} 
Ivan Fedorov's account of how he obtained funding for the 1574 edition of the Apostol reveals his specifically Muscovite attitude to patronage. The master resorted to Biblical motifs describing poor widows contributing their two coins to his enterprise, and, at the same time, completely omitted receipt of a major credit. Whether Ivan Fedorov actually received anything from those widows or not, he praised donations, not loans. ${ }^{98}$ This was in line with the Muscovite pattern of patronage when the tsar generously sponsored Ivan Fedorov's press, obviously without expecting repayment in cash. Finally, the format of references to Ivan Fedorov's royal patron in Moscow is also significant for our understanding of the printer's identity. The colophon of the L'viv Apostol calls Ivan IV tsar. This was a controversial decision because the ruling circles of the Commonwealth did not recognize the imperial title of the Muscovite ruler. Even Ruthenian Orthodox like Vasyl'Kostiantyn Ostroz'kyi, who saw Ivan IV as a patron of Orthodoxy, refrained from calling him tsar in print. ${ }^{99}$ Ivan Fedorov's persistent use of the mechanism and language of Muscovite patronage testifies to his Muscovite origin. ${ }^{100}$

The intellectual outlook of Muscovite high-ranking patrons of printing was narrower than the ambitious printing programs of Ruthenian magantes. ${ }^{101}$ It was the patronage of Hryhorii Khodkevych and Vasyl'-Kostiantyn Ostroz'kyi that prompted Ivan Fedorov to publish diverse texts ranging from primers through poems to the full Bible in various languages (Church

\footnotetext{
${ }^{98}$ Viise, Culture, 121, 133.

${ }^{99}$ Bibliia (Ostroh: Ivan Fedorov, 1581), fol. [3] (first sequence).

${ }^{100}$ The dynamics of Ivan Fedorov's self-identification also suggests that he originated from Moscow. Unlike Petr Mstislavets, Ivan Fedorov never indicated his origin in his Moscow editions, a sign that he was at home and did not need to explain that. Having moved to the Grand Duchy he began to describe himself as a Muscovite (Moskvitin) and as Ivan, son of Fedor from Moscow (z Moskvy). For a confused assertion about Ivan Fedorov's Ruthenian background, see Nemirovskii, Ivan Fedorov v Belorussii, 6-10. On his Muscovite origin, see Isaevych, Literaturna spadshchyna, 30.

${ }^{101}$ Nothing supports V.A. Romodanovskaia's wishful thinking on plans to print the full Bible in Moscow long before the Ostroh edition. She refers to several manuscript copies of the Gennadii Bible dating to the 1550 s as evidence of such intentions. But there are dozens and dozens of Muscovite manuscript that have survived in several copies, and this does not mean that they all were supposed to be printed. Even if one assumes some impact of printing on the Muscovite copies of the Gennadii Bible, the fact they were reproduced manually indicates an asymmetrical response to printing within the traditions of Muscovite manuscript culture. See V.A. Romodanovskaia, "Gennadievskaia Bibliia," in Pravoslavnaia entsiklopediia, http://www.pravenc.ru/text/162049.html\#part_4 (accessed 3 March 2017).
} 
Slavonic, local variants of East Slavonic and Greek). Regional peculiarities, however, should not overshadow the integrating function of printing, especially in Church Slavonic, which easily transcended political boundaries. Ivan Fedorov's repertoire remained profoundly religious after his removal to the Grand Duchy of Lithuania: most of his editions were still Orthodox texts plus a few schooling and reference publications that again were aids for reading devotional books. The printing of books in Cyrillic differed from that in Latin not because of different forms of patronage, but because of cultural filters, first of all different modes of engagement with text, whether handwritten or printed, in Western and Eastern Christianity. ${ }^{102}$

The mechanism of patronage had many common features in various pre-modern societies. The institutional patronage of the crown and the church was always desirable for printers because it guaranteed a constant flow of orders. In their turn, royal and clerical patrons enhanced their political and hierarchical position by promoting their positive images in printed books. Both Ivan IV's court and the Orthodox church were exposed to printed culture and responded to it in a variety of ways. As it was in other patronage systems, there was no single approach to the press despite centralized institutional patronage in Moscow. Royal and clerical patrons of printing had different priorities depending on their social status and the type of literacy they commanded. Ivan IV benefitted from printed editions which disseminated his image of a mighty and pious ruler. High-ranking clerics provided printers with literary expertise and spiritual support.

Even within the Orthodox church attitudes toward printing varied, not dissimilar to the Latin church which "did not have a single, general relationship with the printing press."103 Deprived of colophons and even the names of printers, the editions of the anonymous press, which operated under Metropolitan Makarii, suggest a utilitarian, functionalist approach to the printed book. On the contrary, during Metropolitan Afanasii's tenure, Ivan Fedorov and Petr Mstislavets printed books with complex discursive colophons. These colophons defined the Muscovite narrative of patronage which was expressed in tendentious historicized accounts and manipulative chronological records. Unlike the output

\footnotetext{
102 On cultural filters, see Simon Franklin's paper in this collection.

${ }^{103}$ Nowakowska, "High clergy," 64.
} 
of the anonymous press, books produced by different teams of printers under Afanasii reveal intensive work on format and text. ${ }^{104}$ These innovative features should be attributed to Afanasii's patronage that encouraged creative engagement with the text of printed editions.

When Ivan Fedorov and Petr Mstislavets lost the protection of Afanasii, they did what they would later do in a similar situation in Poland-Lithuania: the printers moved to another patron. However, the centralization of printing in Muscovy severely restricted their choice. As Muscovy had no private or local sponsors of printing, the masters had no other option but to leave the country. Still, despite emigration (or, in the case of Petr Mstislavets, probably repatriation) to Poland-Lithuania, the printers sought to employ at their new location the model of patronage that they learned to operate in Moscow. Even in L'viv, arguably, the most Westernized of all places where Ivan Fedorov happened to work, he utilized his Muscovite experience of patronage in attempts to find new patrons.

Despite the limitations of her study, Eisenstein correctly emphasizes the cosmopolitan nature of printing. Printers bridged many worlds by encouraging cross-cultural interchange and collaboration. ${ }^{105}$ The printing enterprise of Ivan Fedorov also brought together printers, royalty, clerics, merchants and magnates. All these people contributed to the exchange of cultural, technological, administrative and financial resources that resulted in the appearance and distribution of Ivan Fedorov's editions in Muscovy, Ruthenia and other lands.

\footnotetext{
${ }^{104}$ For a comparative analysis of the 1564 Apostol and the Gospels published by the anonymous press, see Koliada, "Rabota," 227-228. On editing the 1564 Apostol, see also Ralph Cleminson's paper in this volume. On differences between the 1568 Psalter commissioned by Afanasii and earlier printed editions of the book, see Voznesenskii, $K$ istorii, 66, 115, 120, 123, 175, 193, 194, 217, 218.

105 Eisenstein, Printing Press, 55-56; Eisenstein, “An Unacknowledged Revolution,” 90.
} 
Appendix I. Dating Systems in Ivan Fedorov's Editions

\begin{tabular}{|c|c|c|c|c|c|c|c|}
\hline No. & $\begin{array}{l}\text { Edition or } \\
\text { variant }\end{array}$ & AM year & AD year & $\begin{array}{l}\text { Regnal } \\
\text { year of } \\
\text { monarch }\end{array}$ & $\begin{array}{l}\text { Regnal year } \\
\text { of } \\
\text { metropolitan }\end{array}$ & Regnal note & $\begin{array}{l}\text { Feast } \\
\text { day }\end{array}$ \\
\hline \multirow[t]{3}{*}{1} & \multirow{3}{*}{$\begin{array}{l}\text { Acts and } \\
\text { Epistles, } \\
\text { Moscow, } \\
1564\end{array}$} & 7061 & & $\begin{array}{l}30^{\text {th }} \text { (sic) } \\
\text { of Ivan IV }\end{array}$ & & & \\
\hline & & 19.04 .7071 & & & & & $\begin{array}{l}\text { Ioann of } \\
\text { the } \\
\text { Ancient } \\
\text { Caves }\end{array}$ \\
\hline & & 01.03 .7072 & & & $1^{\text {st }}$ of Afanasii & & \\
\hline \multirow[t]{2}{*}{2} & \multirow{2}{*}{$\begin{array}{l}\text { Book of } \\
\text { Hours, } \\
\text { Moscow, } \\
29.09 .1565\end{array}$} & 07.08 .7073 & & & & & \\
\hline & & 29.09 .7074 & & $\begin{array}{l}31^{\text {st }} \text { (sic) } \\
\text { of Ivan IV }\end{array}$ & $2^{\text {nd }}$ of Afanasii & & \\
\hline \multirow[t]{2}{*}{3} & \multirow{2}{*}{$\begin{array}{l}\text { Book of } \\
\text { Hours, } \\
\text { Moscow } \\
29.10 .1565\end{array}$} & 02.09 .7073 & & & & & \\
\hline & & 29.10 .7074 & & $\begin{array}{l}31^{\text {st }} \text { (sic) } \\
\text { of Ivan IV }\end{array}$ & $2^{\text {nd }}$ of Afanasii & & \\
\hline \multirow[t]{3}{*}{4} & \multirow[t]{3}{*}{$\begin{array}{l}\text { Homiliary } \\
\text { Gospel, } \\
\text { Zabłudów, } \\
1569\end{array}$} & & & & & $\begin{array}{l}\text { Sigismund II } \\
\text { August, } \\
\text { Metropolitan } \\
\text { Iona of Kyiv } \\
\text { and Halych }\end{array}$ & \\
\hline & & & 08.07 .1568 & & & & \\
\hline & & & 17.03 .1569 & & & & \\
\hline \multirow[t]{3}{*}{5} & \multirow{3}{*}{$\begin{array}{l}\text { Psalter and } \\
\text { Book of } \\
\text { Hours, } \\
\text { Zabłudów, } \\
1570\end{array}$} & & 26.09 .1569 & & & & \\
\hline & & & 23.03 .1570 & & & & \\
\hline & & & & & & $\begin{array}{l}\text { Sigismund II } \\
\text { August }\end{array}$ & \\
\hline \multirow[t]{3}{*}{6} & \multirow{3}{*}{$\begin{array}{l}\text { Acts and } \\
\text { Epistles, } \\
\text { L'viv, } 1574\end{array}$} & 7071 & & $\begin{array}{l}30^{\text {th }} \text { of } \\
\text { Ivan IV }\end{array}$ & & & \\
\hline & & & 25.02 .1573 & & & & \\
\hline & & & 15.02 .1574 & & & & \\
\hline 7 & $\begin{array}{l}\text { Primer, } \\
\text { L'viv, } 1574\end{array}$ & & 1574 & & & & \\
\hline 8 & $\begin{array}{l}\text { Primer, } \\
\text { Ostroh, } \\
1578 \\
\end{array}$ & 7086 & 18.06 .1578 & & & & \\
\hline 9 & $\begin{array}{l}\text { Bible, } \\
\text { Ostroh, } \\
1580 \\
\text { (cancelled } \\
\text { leaves in } \\
\text { the } 1581 \\
\text { edition, see } \\
\text { no. 13) }\end{array}$ & 7088 & 12.07 .1580 & & & & \\
\hline 10 & $\begin{array}{l}\text { Psalter and } \\
\text { New } \\
\text { Testament, } \\
\text { Ostroh, } \\
1580 \\
\end{array}$ & 7000 (sic) & 1580 & & & & \\
\hline 11 & Index to the & 7089 & 1580 & & & & \\
\hline
\end{tabular}




\begin{tabular}{|l|l|l|l|l|l|l|l|}
\hline No. & $\begin{array}{l}\text { Edition or } \\
\text { variant }\end{array}$ & AM year & AD year & $\begin{array}{l}\text { Regnal } \\
\text { year of } \\
\text { monarch }\end{array}$ & $\begin{array}{l}\text { Regnal year } \\
\text { of } \\
\text { metropolitan }\end{array}$ & Regnal note & $\begin{array}{l}\text { Feast } \\
\text { day }\end{array}$ \\
\hline $\begin{array}{l}\text { New } \\
\text { bestament } \\
\text { Mikhailovic } \\
\text { h, Ostroh, } \\
\text { 1580, Sept- } \\
\text { Dec1 }\end{array}$ & & & & & & \\
\hline 12 & $\begin{array}{l}\text { Chronology } \\
\text { by Andrei } \\
\text { Rymsha, } \\
\text { Ostroh, } \\
1581\end{array}$ & & 5.05 .1581 & & & & \\
\hline 13 & $\begin{array}{l}\text { Bible, } \\
\text { Ostroh, } \\
1581\end{array}$ & 7089 & 12.08 .1581 & & & & \\
\hline
\end{tabular}

\footnotetext{
${ }^{1}$ The AM year of publication enables one to date the Index more precisely to the period from 1 September to 31 December 1580 than the general date of 1580 which usually appears in bibliographies. Most specialists believe that the Index was a supplement to the Psalter and the New Testament (no. 10), but Nemirovskii sees it as a separate edition because the Index has a title page. Ia.D. Isaevych has argued that the Index could serve in both capacities. Nemirovskii, Ivan Fedorov i ego epokha, 441-442; Isaevych, Literaturna spadshchyna, 124-125.Textual analysis confirms Isaevych's view. The compiler Timofei Mikhailovich intended his Index as a part of the New Testament, as apparent from his description of the work: The Collection of the Most Necessary Things to Find [Them] Promptly in This Book of the New Testament (Sobranie veshchei nuzhneishikh" skorago radi obreteniia vo knize sei Novago Zaveta). Ivan Fedorov added to the Index a title page that reproduced the above-quoted description, but with a new generic definition (Little Book, Knizhka) and without the word this in the reference to the New Testament ( $v$ " knize Novago Zaveta). Timofei Mikhailovich, comp., Knizhka, sobranie veshchei nuzhneishikh" (Ostroh: Ivan Fedorov, 1580), title page, fol. 1 (Cambridge, University Library, Bible Society Collection, 254B80). These alterations enabled the distribution of the Index both together with the New Testament as Timofei Mikhailovich originally planned and as a separate book. The title page of the Index was thus a marketing tool rather than an element of a separate edition.
} 


\section{Appendix II. Muscovite Royal Titles in Early Cyrillic Editions}

\begin{tabular}{|c|c|c|c|c|c|c|c|}
\hline \multirow[t]{2}{*}{ No } & \multirow[t]{2}{*}{ Title } & \multicolumn{4}{|c|}{$\begin{array}{l}\text { Ivan Fedorov's and Petr Mstislavets' editions, } \\
\text { fols. }\end{array}$} & \multicolumn{2}{|c|}{ Other editions, fols. } \\
\hline & & $\begin{array}{l}\text { Acts and } \\
\text { Epistles, } \\
\text { Moscow, } \\
1564\end{array}$ & $\begin{array}{l}\text { Book of } \\
\text { Hours, } \\
\text { Moscow, } \\
1565,1^{\text {st }} \\
\text { ed. }\end{array}$ & $\begin{array}{l}\text { Book of } \\
\text { Hours, } \\
\text { Moscow, } \\
1565,2^{\text {nd }} \\
\text { ed. }\end{array}$ & $\begin{array}{l}\text { Acts and } \\
\text { Epistles, } \\
\text { L'viv, } 1574\end{array}$ & $\begin{array}{l}\text { Psalter, } \\
\text { Moscow, } \\
1568\end{array}$ & $\begin{array}{l}\text { Psalter, } \\
\text { Sloboda, } \\
1577\end{array}$ \\
\hline 1 & $\begin{array}{l}\text { Blagochestivyi tsar' i velikii kniaz' Ivan } \\
\text { Vasilievich vseia velikiia Rosiia } \\
\text { samoderzhets } \\
\text { (Pious Tsar and Great Prince Ivan Vasil'evich, } \\
\text { Autocrat of All Great Russia) }\end{array}$ & 260 & & & & & \\
\hline 2 & $\begin{array}{l}\text { Blagovernyi tsar' } \\
\text { (Faithful Tsar) }\end{array}$ & $\begin{array}{l}260 \\
260 \mathrm{v} .\end{array}$ & & & & & \\
\hline 3 & $\begin{array}{l}\text { Blagochestivyi tsar' i velikii kniaz' Ivan } \\
\text { Vasil'evich vseia Rusii } \\
\text { (Pious Tsar and Great Prince Ivan Vasil'evich } \\
\text { of All Rus') }\end{array}$ & $260 v$ & & & 260 & & \\
\hline $4 a$ & $\begin{array}{l}\text { Erroneous: } \\
\text { Slavnyi i mudroliubivyi nad tsari tsar' i velikii } \\
\text { kniaz' Ivan Vasilievich } \\
\text { (Glorious and Wisdom-Loving, [Ruling] over }\end{array}$ & & $171 v$ & & & & \\
\hline
\end{tabular}




\begin{tabular}{|c|c|c|c|c|c|c|c|}
\hline \multirow[t]{2}{*}{ No } & \multirow[t]{2}{*}{ Title } & \multicolumn{4}{|c|}{$\begin{array}{l}\text { Ivan Fedorov's and Petr Mstislavets' editions, } \\
\text { fols. }\end{array}$} & \multicolumn{2}{|c|}{ Other editions, fols. } \\
\hline & & $\begin{array}{l}\text { Acts and } \\
\text { Epistles, } \\
\text { Moscow, } \\
1564\end{array}$ & $\begin{array}{l}\text { Book of } \\
\text { Hours, } \\
\text { Moscow, } \\
1565,1^{\text {st }} \\
\text { ed. }\end{array}$ & $\begin{array}{l}\text { Book of } \\
\text { Hours, } \\
\text { Moscow, } \\
1565,2^{\text {nd }} \\
\text { ed. }\end{array}$ & $\begin{array}{l}\text { Acts and } \\
\text { Epistles, } \\
\text { L'viv, 1574 }\end{array}$ & $\begin{array}{l}\text { Psalter, } \\
\text { Moscow, } \\
1568\end{array}$ & $\begin{array}{l}\text { Psalter, } \\
\text { Sloboda, } \\
1577\end{array}$ \\
\hline & $\begin{array}{l}\text { [Other] Tsars Tsar and Great Prince Ivan } \\
\text { Vasil'evich) }\end{array}$ & & & & & & \\
\hline $4 b$ & $\begin{array}{l}\text { Corrected: } \\
\text { Slavnyi i mudroliubivyi nad tsari tsar' i velikii } \\
\text { kniaz' Ivan Vasilievich vseia velikiia Rosiia } \\
\text { samoderzhets } \\
\text { (Glorious and Wisdom-Loving, [Ruling] over } \\
\text { [Other] Tsars Tsar and Great Prince Ivan } \\
\text { Vasil'evich, Autocrat of All Great Russia) }\end{array}$ & & & $170 v-171$ & & & \\
\hline 5 & $\begin{array}{l}\text { Tsar' i velikii kniaz' Ivan Vasilievich vseia } \\
\text { Rusii samoderzhets } \\
\text { (Tsar and Great Prince Ivan Vasil'evich, } \\
\text { Autocrat of All Rus') }\end{array}$ & & 173 & 172 & & & \\
\hline 6 & $\begin{array}{l}\text { Gosudar' } \\
\text { (Sovereign) }\end{array}$ & & & & 260 & & \\
\hline 7 & $\begin{array}{l}\text { Krestonosnyi i bogovenchannyi i bogomudryi } \\
\text { nad tsar'mi tsar', vernyi Bozhii sluga velikii }\end{array}$ & & & & & 289 & \\
\hline
\end{tabular}




\begin{tabular}{|c|c|c|c|c|c|c|c|}
\hline \multirow[t]{2}{*}{ No } & \multirow[t]{2}{*}{ Title } & \multicolumn{4}{|c|}{$\begin{array}{l}\text { Ivan Fedorov's and Petr Mstislavets' editions, } \\
\text { fols. }\end{array}$} & \multicolumn{2}{|c|}{ Other editions, fols. } \\
\hline & & $\begin{array}{l}\text { Acts and } \\
\text { Epistles, } \\
\text { Moscow, } \\
1564\end{array}$ & $\begin{array}{l}\text { Book of } \\
\text { Hours, } \\
\text { Moscow, } \\
1565,1^{\text {st }} \\
\text { ed. }\end{array}$ & $\begin{array}{l}\text { Book of } \\
\text { Hours, } \\
\text { Moscow, } \\
\text { 1565, } 2^{\text {nd }} \\
\text { ed. }\end{array}$ & $\begin{array}{l}\text { Acts and } \\
\text { Epistles, } \\
\text { L'viv, 1574 }\end{array}$ & $\begin{array}{l}\text { Psalter, } \\
\text { Moscow, } \\
1568\end{array}$ & $\begin{array}{l}\text { Psalter, } \\
\text { Sloboda, } \\
1577\end{array}$ \\
\hline & $\begin{array}{l}\text { kniaz' Ivan Vasilievich vseia velikiia Rosiia } \\
\text { samoderzhets } \\
\text { (Cross-bearing and God-crowned and God- } \\
\text { enlightened Tsar [Reigning over Other] } \\
\text { Tsars, God's Faithful Servant, Grand Prince } \\
\text { Ivan Vasilievich, Autocrat of All Great Russia) }\end{array}$ & & & & & & \\
\hline 8 & $\begin{array}{l}\text { Blagochestivyi tsar' } \\
\text { (Pious Tsar) }\end{array}$ & & & 172 & $171 v$ & $289 v$ & \\
\hline 9 & $\begin{array}{l}\text { Tsar' i velikii kniaz' Ivan Vasilievich vseia } \\
\text { Rusii } \\
\text { (Tsar and Great Prince Ivan Vasil'evich of All } \\
\text { Rus') }\end{array}$ & & & & & $290 v$ & \\
\hline 10 & $\begin{array}{l}\text { Blagochestivyi i Bogom venchannyi i } \\
\text { khorugvepraviashchii skipetra velikiia Rusii } \\
\text { gosudar' tsar' i velikii kniaz' Ivan Vasilievich } \\
\text { vseia Rusii samoderzhets } \\
\text { (Pious and God-crowned Sovereign Reigning } \\
\text { with the Sceptre of Great Rus', Tsar and Great } \\
\text { Prince Ivan Vasil'evich, Autocrat of All Rus') }\end{array}$ & & & & & & $278 v$ \\
\hline
\end{tabular}




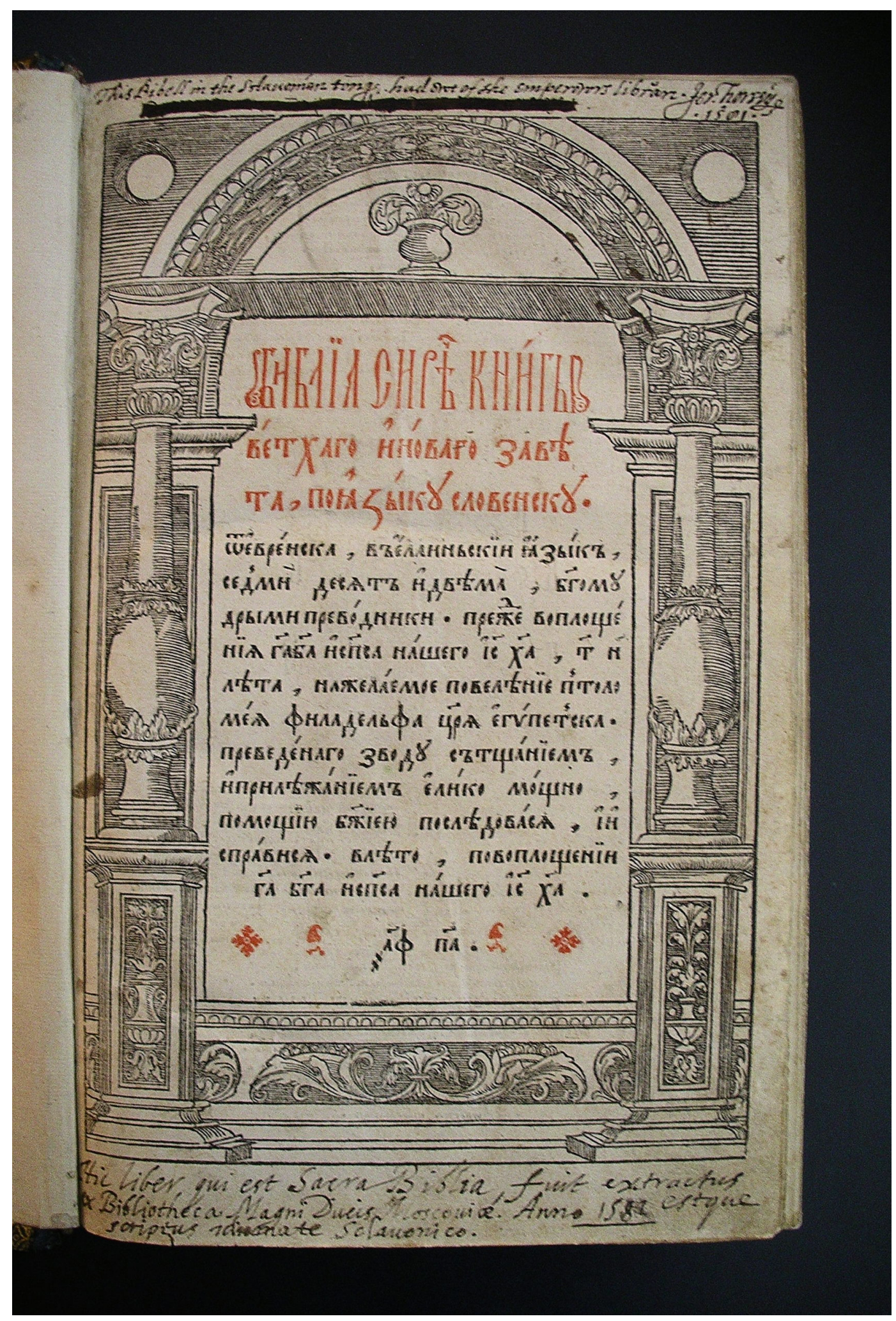

Fig. 1. Notations in Jerome Horsey's copy of the Ostroh Bible. British Library, G.12203, fol. [1] (first sequence). 


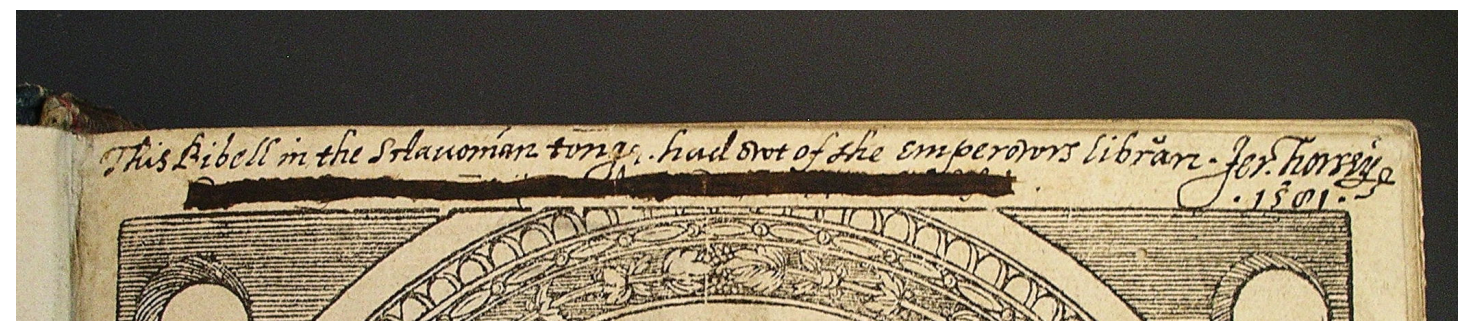

Fig. 2. English notation in Horsey's copy of the Ostroh Bible: This Bibell in the Sclavonian tonge had out of the Emperotors librari. Jer. Horsey. 1581. Blacked out text. British Library, G.12203, fol. [1] (first sequence), top margin.

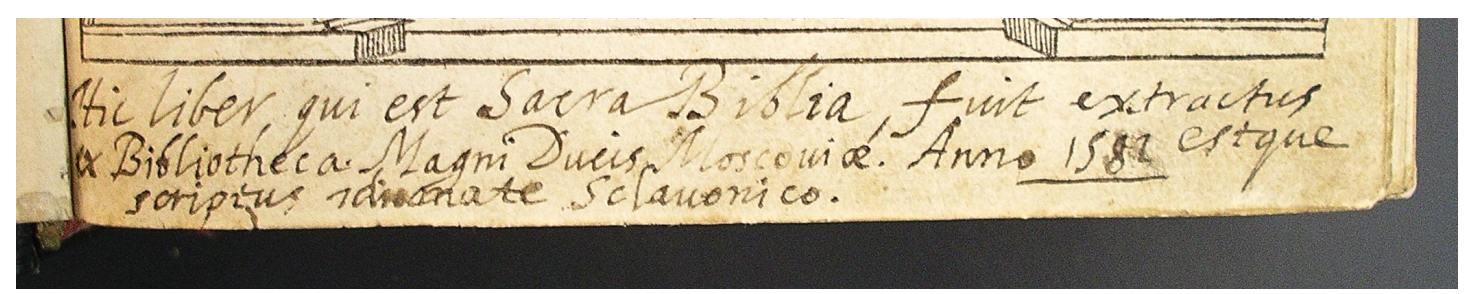

Fig. 3. Latin notation in Horsey's copy of the Ostroh Bible: Hic liber, qui est Sacra Biblia, fuit extractus ex Bibliotheca Magni Ducis Moscoviae. Anno 1581[2-?] estque scriptus idiomate Sclavonico. British Library, G.12203, fol. [1] (first sequence), bottom margin. 